\title{
COMMODITY EXCHANGES AND THE PRIVATIZATION OF THE AGRICULTURAL SECTOR IN THE COMMONWEALTH OF INDEPENDENT STATES-NEEDED STEPS IN CREATING A MARKET ECONOMY
}

\author{
Alexander Belozertsev* and Jerry W. Markham**
}

\section{INTRODUCTION}

This century has been marked by events that history may well record as turning points for mankind. Two world wars, the creation and use of weapons of mass destruction, the landing of men on the moon, and the technological revolution that ensued have triggered momentous changes in world society. No less dramatic and undoubtedly as far-reaching in effect are the events that are now underway in the former Soviet Union-now the Commonwealth of Independent States ("CIS"). Perestroika (restructuring), glasnost (openness), a failed coup, ${ }^{1}$ the rejection of the communist party and the splintering of the Soviet republics have gripped the attention of the world. ${ }^{2}$ Those events were preceded by a "cold war" that was fueled in no small measure by the issue of whether Soviet state planning was preferable to the market economies of Western countries, particularly the United States. Clearly, the market economy has emerged as the preferred order, despite its inequalities and harshness to those who are unable or unwilling to compete.

\footnotetext{
Copyright $\odot 1992$ by Law and Contemporary Problems

* Agricultural Economist, Moscow, Russia. Mr. Belozertsev recently spent several months in the United States studying the operations of our commodity markets.

* Associate Professor of Law, University of North Carolina at Chapel Hill.

1. See Gorbachev Says Coup Will Hasten Reform: Yeltsin Leads the Celebration in Moscow, NY Times Al col 6 (Aug 23, 1991); Felicity Barringer, Chronicle of the Resistance: 48 Tense Hours in Leningrad, NY Times Al col 5 (Sept 10, 1991).

2. See Serge Schmemann, Yeltsin Sweeps up Crucial Remnants of Withering Union, NY Times Al col 6 (Dec 20, 1991); Serge Schmemann, Gorbachev, Yeltsin and Republic Leaders Move to Take Power From Soviet Congress, NY Times Al col 6 (Sept 3, 1991); Andrew Rosenthal, Baltics Recognized, NY Times A 1 col 3 (Sept 3, 1991); Celestine Bohlen, Gorbachev and Yeltsin, Tense Allies, Push Union Plan, NY Times Al col 6 (Sept 4, 1991); Serge Schmemann, Soviet Congress Yields Rule to Republics to Avoid Political and Economic Collapse, NY Times Al col 6 (Sept 6, 1991); Serge Schmemann, Soviets Recognize Baltic Independence, Ending 51-Year Occupation of 3 Nations, NY Times A1 col 6 (Sept 7, 1991); Mikhail Gorbachev, The August Coup (Harper Collins, 1991).
} 
One of the major tasks now facing the CIS is the implementation of the market economy ideal in the agriculture sector. ${ }^{3}$ A significant step in that direction is the development of an exchange-based distribution system that will provide a mechanism for the exchange and valuation of grains. Some fledgling exchanges are already operating in the CIS. They are, however, principally non-agricultural barter operations that will not provide the necessary mechanism for the free flow of commodities that is so vital to the operation of a market economy.

This article reviews pre-revolutionary exchanges in Russia and their extinguishment by the Bolsheviks. It describes the role played thereafter by Soviet central planners in the distribution, import, and export of agricultural commodities. The article then reviews the history and economic role played by commodity exchanges in the United States and demonstrates why a sophisticated commodity exchange system is needed in the CIS. Although the ultimate relationship among the former Soviet republics remains uncertain as of this writing, ${ }^{4}$ whatever the outcome may be, the proposals in this article apply equally to the individual states in the CIS as well as to any joint arrangements that may emerge from the current restructuring. For example, the proposed steps that the former Soviet republics must take to establish a commodity exchange system are applicable individually or jointly.

The privatization process in the CIS must include incentives for the development of an exchange system for agricultural goods. This process would include, for example, the sale of land in exchange for the production and delivery of grain to an exchange distribution point or some other external location that will assure distribution to consumers and processors. As an additional incentive, the purchase price could be reduced by increased production. This exchange of land for grain would provide an equitable land distribution method. Such a program would also provide powerful incentives to increase the output of the currently inefficient farms in the Soviet republics.

3. See generally Alan Riding, Europeans Hope Soviets Will Quicken Shift to Market System, NY Times A13 col 1 (Aug 23, 1991).

4. See generally John Lloyd, Minsk Economic Summit Threatens to Split Republics, Fin Times 1 col 3 (Dec 30, 1991); Thomas L. Friedman, Gorbachev Rejects Move to Discard Kremlin Role: U.S. Keeps Link to Moscow, NY Times Al col 4 (Dec 10, 1991); Serge Schmemann, Gorbachev Warns Soviets About 'Crisis of Statehood; NY Times A8 col 5 (Dec 4, 1991); Francis X. Clines, Independent Ukraine Keeps Sight of Cooperation, NY Times A8 col 1 (Dec 4, 1991); Chrystia Freeland, Ukrainians Pin Their Hopes on Independence, Fin Times 2 col 2 (Dec 2, 1991); Chrystia Freeland, John Lloyd \& George Graham, Ukraine Votes for Full Independence by 9 to 1, Fin Times 1 col 3 (Dec 3, 1991); Neela Banerjee, Russians Try to Survive Financial Chaos, Wall St J A11 col 1 (Dec 3, 1991); John Lloyd, Russia Plans Polish Style Economic Shake-Up, Fin Times 1 col 3 (Nov 14, 1991); Serge Schmemann, 7 Soviet Republics Agree to Work for New Union, NY Times A6 col 4 (Nov 15, 1991); Gerald F. Seib, U.S. Loses Hope That Coherent Economy Will Link Nationalistic Soviet Republics, Wall St J A12 col 5 (Oct 28, 1991); Serge Schmemann, Ukraine Is Now Getting Serious About Its Drive for Independence, NY Times Al col 3 (Oct 30, 1991); John Lloyd, Yeltsin's Bitter Pill, Fin Times 20 col 3 (Oct 29, 1991); Celestine Bohlen, Warning of 'Abyss' Gorbachev Demands Republics Cooperate, NY Times Al col 1 (Nov 5, 1991); Hesitant Ukraine to Sign Soviet Economic Treaty, Wall St J Al5 col 3 (Nov 5, 1991); Celestine Bohlen, Ukraine, Biggest Holdout, Signs Economic Link to Soviet Republics, NY Times A7 col 1 (Nov 7, 1991); John Lloyd, Gorbachev Warns Russia Not to Go It Alone, Fin Times 20 col 1 (Nov 5, 1991); Ian Davidson, David Marsh, George Graham, \& Quentin Peel, West Ponders Value of Shoring up Soviet Centre, Fin Times 2 col 6 (Nov 5, 1991); Anders Aslund, Forget the Soviet Union, NY Times A13 col 4 (Nov 8, 1991). 
It also would assure that grain reaches processors and consumers instead of rotting in the fields, as occurs now for some thirty percent of production. ${ }^{5}$

The correction of current distribution problems in the CIS will also require the aid of brokers and middlemen who can ferret out, purchase and arrange for distribution of grain to market centers. Such private entrepreneurs were an almost non-existent class in the former Soviet Union. Incentives are needed to create this necessary element of any market economy. These middlemen should be provided loans and grants that could be repaid or forgiven, in whole or in part, on the basis of the number of bushels of grain transported from the farms to processors and consumers.

Numerous practical problems must also be overcome before an effective exchange distribution system can be implemented. Among other things, modern communication facilities are needed and exchange concepts such as clearing houses must be created to confirm and guarantee trades. Basic commercial mechanisms such as default provisions and dispute resolution mechanisms are also needed, as well as technical assistance in developing the exchanges and making the distribution system work.

This article advocates the assistance of the United States in this effort. Nevertheless, the authors agree with the critics of the so-called "Grand Bargain" of massive relief to the CIS. ${ }^{6}$ The use of aid merely to make up for shortfalls caused by the present system will only prolong the agony of the transformation process. The United States would be much better advised to use its resources and technological know-how to develop a functioning exchange distribution system in the CIS. Incentives and technical assistance would permit the development of the infrastructure that is now so desperately needed for the conversion to a true market economy.

\section{II}

\section{A Historical Review of the Soviet Economy}

\section{A. The Russian Commodity Exchanges}

The formal exchange of commodities began in Russia in the twelfth century with gatherings of merchants at agricultural trade fairs. ${ }^{7}$ By 1865 , there were over 6,500 fairs. In fact, they were the principal mechanism for the exchange of goods in Russia until the latter part of the nineteenth century. ${ }^{8}$

5. See notes $184,193,196$.

6. Under the "Grand Bargain," the republics would be given massive aid in exchange for promises of market reform. Moscow Calling, The Economist 15 (Sept 7, 1991); American Survey: Posttriumphal Depression, The Economist 19 (Aug 31, 1991). See also West Lockhart, Soviet Aid Request Needs Scrutiny, Experts Say, The Daily Tarheel 4 col 3 (Oct 2, 1991) (criticism of relief efforts that would delay reform by allowing Soviets to delay confronting existing barriers to market reform); Paul Blustein, Leading Industrial Nations Split Over Plan for Soviet Debt Relief, Wash Post A39 col 1 (Oct 13 , 1991) (concern expressed over debt service deferrals for the Soviet Union).

7. Joseph L. Wieczynski, ed, 4 The Modern Encyclopedia of Russian and Soviet History 184 (Acad Intl Press, 1977) ("Modern Encyclopedia").

8. Peter I. Lyashchenko, History of the National Economy of Russia to the 1917 Revolution 500 (Macmillan Co., 1949). 
The largest and best known of the fairs was held at Nizhnii Novgorod. ${ }^{9}$ It attracted business from all over East Asia, from Persia to China. In 1838, the Nizhnii Novgorod fair had sales of over 130 million rubles. ${ }^{10}$

More formal exchanges were slow to develop in Russia. "[U]nlike in Western Europe, the government, and not the merchantry, took the initiative in creating the first commercial exchange (birzha)."11 That exchange was organized in 1703 by Peter the Great, who had been impressed by the exchanges in London and Amsterdam. ${ }^{12}$ Some twenty years later, he also ordered a new building for that exchange to be constructed on Petersburg Island. ${ }^{13}$

The Petersburg exchange relied chiefly on the self-regulation of members for its governance. ${ }^{14}$ Nevertheless, government regulations were imposed on the exchange to prohibit "fighting, spreading unfounded rumors, engaging in political discussions, and trading in paper securities ...."15 A particularly contentious issue was the setting of trading hours. ${ }^{16}$ The trading of futures was also prohibited until 1893.17

The Petersburg exchange continued to trade commodities for many years, but it gradually became more predominant in securities trading, listing over 300 securities. ${ }^{18}$ Other commodity exchanges were being created, but their

9. Id at 500. See also Arcadius Kahan, Russian Economic History: The Nineteenth Century 36 (U Chicago Press, 1989).

10. Sergei Pushkarev, The Emergence of Modern Russia: 1801-1917 50 (Holt, Rinehart \& Winston, 1963). See also William L. Blackwell, ed, Russian Economic Development from Peter the Great to Stalin 7476 (New Viewpoints, 1974) (Nizhni Novgorod Fair played large role in setting prices for iron). See generally Jo Ann Ruckman, The Moscow Business Elite: A Social and Cultural Portrait of Two Generations, 1840-1905 35 (N Ill U Press, 1984) (governing body of Nizhni Novgorod fair asks government to restrict travelling salesmen because they compete unfairly with the fair); Fernand Braudel, 3 The Perspective of the World: Civilization and Capitalism 15th-18th Century 445-46 (Harper \& Row, 1979) (description of early trading activities in Russia).

11. Alfred J. Rieber, Merchants and Entrepreneurs in Imperial Russia 21 (U North Carolina Press, 1982) ("Merchants and Entrepreneurs").

12. Id at 21; Wieczynski, Modern Encyclopedia at 184 (cited in note 7); 3 Great Soviet Encyclopedia 672 (Macmillan, 1973) ("Soviet Encyclopedia"). See also James Mavor, An Economic History of Russia 116-17 (E.P. Dutton, 1914) (discussing the formulation of Peter the Great's economic views as a result of his visit to Western Europe).

13. Wieczynski, Modern Encyclopedia at 184 (cited in note 7). The following is an apt description of the exchanges during this period:

An Exchange was, relatively speaking, like the top section of a fair, but one in permanent session. Because the important businessmen as well a host of intermediaries met here, business of every sort could be transacted: operations in commodities, currency exchange, shareholding, maritime insurance ... and it was also a money market, a finance market and a stock market.

Fernand Braudel, 2 The Wheels of Commerce: Civilization and Capitalism 15th-18th Century 100 (Harper \& Row, 1979).

14. Wieczynski, Modern Encyclopedia at 185 (cited in note 7).

15. Rieber, Merchants and Entrepreneurs at 21 (cited in note 11).

16. Id.

17. Id at 105. For a description of commodity futures trading in the United States, see notes 139-159 and accompanying text.

18. Wieczynski, Modern Encyclopedia at 185-86 (cited in note 7); Soviet Encyclopedia at 672 (cited in note 12). In 1896, the Kalashnikov Wharf Grain Exchange was opened as a division of the St. Petersburg Exchange. Wieczynski, Modern Encyclopedia at 186 (cited in note 7). 
development took over a century. ${ }^{19}$ In 1796, for example, the Odessa exchange was established for grain trading. ${ }^{20}$ It was followed, at great intervals, by exchange openings in Rybinsk, Nizhnii Novogorod, Kazan, Samara, and Saratov. ${ }^{21}$

Efforts were undertaken in 1839 to bring the Il'inka street trading of the Moscow merchants indoors, but that process was not completed for some time because the merchants preferred informal trading in the often snowcovered street to the comforts of a formal exchange. ${ }^{22}$ " $[\mathrm{T}]$ he exchange committee appealed to the chief of police to forbid these gatherings and to put pressure on the shop owners in the bazaar to conform . . .,"23 but it was not until the 1860 s that the Moscow exchange became an important commercial center. ${ }^{24}$ That role was cemented with the opening of the Moscow Grain Exchange in 1896. ${ }^{25}$

Transactions on the Russian exchanges were reported in bulletins, weekly price lists, and newspapers such as the St. Petersburg Exchange Register and the Commercial Gazette, which was published by the Department of Foreign Trade. ${ }^{26}$ The Russian exchanges, like their European and American counterparts, also began to employ brokers, or middlemen, to facilitate the free flow of business. The government itself used such brokers to handle its grain operations, and brokers proved particularly useful as intermediaries between merchants who did not know or trust each other. ${ }^{27}$

Because of the development of exchanges, the Russian economy began to lose some of its dependence on the trade fairs. Many of the trade fairs evolved into exchanges, but some continued to operate through the latter part of the nineteenth century and even into the twentieth. ${ }^{28}$ One of the

19. Rieber, Merchants and Entrepreneurs at 22 (cited in note 11).

20. Wieczynski, Modern Encyclopedia at 185 (cited in note 7).

21. Id at $\mathbf{1 8 6 .}$

22. Rieber, Merchants and Entrepreneurs at $22-23$ (cited in note 11).

23. Id at 23. See also, Thomas C. Owen, Capitalism and Politics in Russia: A Social History of the Moscow Merchants 1855-1905 15 (Cambridge U Press, 1981) (description of efforts to force the Moscow merchants indoors).

24. Wieczynski, Modern Encyclopedia at 186 (cited in note 7). The preeminence of the Moscow market was foreshadowed by the important role played by the Moscow merchants in the Russian economy since the 16 th and 17 th centuries. Joseph T. Fuhrmann, The Origins of Capitalism in Russia 27-28 (Quadrangle Books, 1972). One observer described trade with Moscow in the 1550s as follows:

[I]n a single morning one might see seven to eight hundred sleds coming and going laden

with grain and salt-fish. . . . Moscow [also] exported grain through merchants who came a

thousand miles from the north to exchange fish, furs and hides for that product.

Id at 28 (footnote omitted). See also Braudel, 2 The Wheels of Commerce at 32 (cited in note 13) ("Every winter in Moscow when the Moskva river froze, shops, booths and stalls were set up on the ice."); Paul Bushkovitch, The Merchants Of Moscow: 1580-1650 (Cambridge U Press, 1980) (discussion of the early role played by Moscow merchants in the Russian economy); George Vernadsky, ed, $A$ Source Book for Russian History From Early Times to 1917826 (Yale U Press, 1972) (discussion of role played by Moscow merchants in Russian economy prior to World War I).

25. Wieczynski, Modern Encyclopedia at 186 (cited in note 7).

26. Id at 187.

27. Rieber, Merchants and Entrepreneurs at 21 (cited in note 11 ).

28. Geoffrey Drage, Russian Affairs 200-03 (Hazell, Watson \& Viney, 1904); Ruckman, The Moscow Business Elite at 193 (cited in note 10). 
principal differences between the two forms of trading was that sales on the exchanges were generally made on the basis of samples and at fixed prices, rather than by the actual display of goods and haggling common to the fairs. ${ }^{29}$

The continuing development of the exchanges also caused the government to regulate them more actively. In 1870 , the authority to control the organization of markets and exchanges was vested in the municipal public administrations. ${ }^{30}$ In the 1890 s, however, the national government began asserting greater control over the exchanges, particularly the St. Petersburg exchange, removing much of its self-regulatory authority. At one point, the Ministry of Finance imposed an absurd requirement that a partition be constructed between the securities and commodities markets on the exchange floor. ${ }^{31}$

Matters began to deteriorate in Moscow when the exchange there attempted to restrict the autocracy, which resulted in a ban on political discussions. World War I further heightened tensions as the Russian government began to disintegrate. ${ }^{32}$

\section{B. The October Revolution}

"Before the [first world] war Russia ranked first among all of the nations of the world in quantity production and export of wheat and was second only to the United States in the total production of cereals . . . "33 At the commencement of the war, there were 115 securities and commodity exchanges in Russia. ${ }^{34}$ Although these exchanges were closed during the war, a black market managed to function. ${ }^{35}$ Hoarding and speculation were widespread. "At the Nizhnyi Novgorod fair speculation had become a mass phenomenon ... 'an all-Russian disgrace bearing the stamp of the all-Russian merchantry." "36

The October Revolution in 1917 resulted in a prohibition of all securities transactions. ${ }^{37}$ The civil war, which lasted from 1918-1920, ${ }^{38}$ also led to "war communism." Under that program, the Bolsheviks "sought to eliminate private enterprise through the nationalization of land, industry and banks, and through the abolition of private trade and money." 39 "Lenin focused his wrath most frequently on the private grain trade, charging that it enriched

29. Drage, Russian Affairs at 202 (cited in note 28).

30. Vernadsky, A Source Book For Russian History From Early Times to 1917 at 621 (cited in note 24).

31. Rieber, Merchants and Entrepreneurs at 106 (cited in note 11).

32. Id at 270-71.

33. Scott Nearing \& Jack Hardy, The Economic Organization of the Soviet Union 47 (Vanguard Press, 1927).

34. Soviet Encyclopedia at 672 (cited in note 12).

35. Id.

36. Rieber, Merchants and Entrepreneurs at 384 (cited in note 11).

37. Wieczynski, Modern Encyclopedia at 187 (cited in note 7).

38. See W. Bruce Lincoln, Red Victory: A History of the Russian Civil War (Simon and Schuster, 1989) (description of the Russian civil war).

39. Colleen Dooling. The Legacy of NEP in Soviet History and Politics 7, unpublished thesis, University of North Carolina at Chapel Hill (1986) ("The Legacy of NEP"). See also E. A. Rees, State Control in Soviet Russia 15 (St. Martin's Press, 1987) (discussion of war communism). 
speculators, impoverished (or starved) the masses, and threatened to drive Russia back to the days of the old regime." 40 Lenin also sought grain from the peasants as a "loan" to the state. ${ }^{41}$ When that appeal failed, the government adopted forced grain requisitions. ${ }^{\mathbf{4 2}}$

These efforts did not eliminate black market transactions or the development of a barter economy. ${ }^{43}$ The peasants responded to the government by slashing production to levels that met only their own needs, ${ }^{44}$ contributing to the deaths of many of the millions who perished during the civil war and war communism. ${ }^{45}$

Widespread dissatisfaction with this state of affairs, along with the sailors' Kronstadt revolt, forced Lenin to announce a New Economic Policy ("NEP") at the Tenth Party Congress in March, 1921.46 Under NEP, the government sought to restore a limited market system and end grain requisitions from the peasants. ${ }^{47}$ Instead, the peasants were taxed initially "in-kind" in grain and any grain produced in excess of the tax could be sold, creating an incentive for increased production. ${ }^{48}$ The peasants were also given tenure of the land, which lasted as long as they kept it cultivated. ${ }^{49}$

40. Alan M. Ball, The Nepmen: Private Entrepreneurs In the Soviet Union, 1921-1929 5, unpublished Ph.D. dissertation, available at the University of North Carolina at Chapel Hill (1982) ("The Nepmen").

41. Id.

42. Arvind Vyas, Sixty Years of Soviet Economic Development, in Zafar Imam, The USSR: Sixty Years 1 (Tulsi Publishing House, 1981). The Soviets intially bartered industrial goods for agriculture production, but that effort was abandoned for requisition programs. Silvana Malle, The Economic Organization of War Communism, 1918-1921 338-80 (Cambridge U Press, 1985) ("Economic Organization").

43. Thomas F. Remington, Building Socialism in Bolshevik Russia: Ideology and Industrial Organization 1917-1921, at 164-65 (U Pittsburgh Press, 1984).

44. Nearing \& Hardy, The Economic Organization of the Soviet Union at 50 (cited in note 33). During war communism, agricultural production fell to a level of about three-fourths that of 1912. Ball, The Nepmen at 11 (cited in note 40). "Bagmen" roamed the country searching for food. Id at 140 . The situation was not improved by the chaotic conditions attending the civil war or by the famine that followed the crop failure in 1921. Nearing \& Hardy, The Economic Organization of the Soviet Union at 50 (cited in note 33 ).

A report of a United States government agency during this period also notes that, "[p]rior to the World War, Rumania and Russia supplied a large proportion of the wheat imports into other European countries. Since the war Russia has not been a factor in supplying the world grain market." Federal Trade Commission, 1 Report of the Federal Trade Commission on Methods and Operations of Grain Exporters at xxii (May 16, 1922) ("Grain Exporters"). Moreover, Russia was one of the world's largest rye exporters. Its drop in rye exports after the war was replaced by grain from the United States. Id at 7. Russian oat production was also decimated. Id at 10.

Following World War I, the United States helped the Soviets overcome commodity shortages by shipping them grain. Dan Morgan, Merchants of Grain 172 (Penguin, 1980).

45. Ball, The Nepmen at $12-13$ (cited in note 40).

46. Peter J. Boettke, The Political Economy of Soviet Socialism: The Formative Years, 1918-1928114 (Kluwer Academic Publishers, 1990) ("Political Economy"); Dooling, The Legacy of NEP at 7 (cited in note 39); Vladimir Dmitrenko, Economic Policy During the Construction of Socialism in the USSR 46 (Progress Publishers, 1987).

47. See Roger Pethybridge, One Step Backwards Two Steps Forward (Clarendon Press, 1990) (history of NEP); Alan M. Ball, Russia's Last Capitalists: The Nepman, 1921-1929 (U of California Press, 1987) (same).

48. Dooling, The Legacy of NEP at 7-8 (cited in note 39).

49. Nearing \& Hardy, The Economic Organization of the Soviet Union at 52-53 (cited in note 33). The land could not be transferred or sold. Id. 
Small entrepreneurs called "Nepmen" were allowed to distribute goods, and for a time they controlled some 75 percent of retail trade. These Nepmen and "their agricultural counterparts, the kulaks, stimulated the economy $\ldots,{ }^{\circ} 50$ and agriculture was restored to pre-war levels. ${ }^{51}$ In addition, urban dwellers became heavily dependent on the Nepmen for their food and clothing. ${ }^{52}$

NEP, however, was not a success, because the government could not refrain from interfering heavily in the economy. ${ }^{53}$ For example, commodity exchanges, which were still numbered over 100 , were used for several years in the NEP period as instruments to regulate prices and curtail speculation. ${ }^{54}$ During the NEP interregnum, the exchanges became "organs for state regulation of the market" and exchange membership was dominated by government bureaus. ${ }^{55}$

The Moscow commodity exchange became the most important of the commodity exchanges used by the Bolshevik government during the NEP period. ${ }^{56}$ It and other exchanges, however, were doomed to lose their appeal because of the new government's ideology. ${ }^{57}$ The exchanges were believed to foster "commodity fetishism," which in communist cant was "the objectification of production relations between people under the conditions of commodity production based on private ownership." 58

To eliminate this fetish, the government thought it necessary to "overthrow" capitalist society. ${ }^{59}$ Moreover, in Trotsky's words, "the socialist

50. Dooling, The Legacy of NEP at 8-9 (cited in note 39).

51. Franklyn D. Holzman, The Soviet Economy: Past, Present and Future 9 (Foreign Policy Association Headline Series, Sept/Oct 1982); Boettke, Political Economy at 118-32 (cited in note 46). See also Stephen F. Cohen, Bukharin and the Bolshevik Revolution: A Political Biography, 1888-1938, at 273 (Oxford U Press, 1971) ("NEP had brought civil peace, political stability, and economic recovery ....."); Gerhard Dobbert, ed, Red Economics xi (Houghton Mifflin Co., 1932) (NEP "set the wheels going again and the chimneys smoking by the stimulus it gave to private production, small in units but vast in volume, and to private trade.").

52. Ball, The Nepmen at 277 (cited in note 40 ).

53. See Boettke, Political Economy at 118 (cited in note 46); Ball, The Nepmen at 287-88 (cited in note 40 ). This was exemplified by the so-called "scissors crisis" when the government established cartels to limit competition that was causing drastic price reductions. Michael Bleaney, Do Socialist Economies Work? The Soriet and East European Experience 8 (Basil Blackwell, 1988) ("Do Socialist Economics Work?" ); Chris Ward, Russia's Cotton Workers and the New Economic Policy 128 (Cambridge U Press, 1990). The scissors crisis was followed by the "goods famine," which was caused by governmentrepressed inflation. Alexander Erlich, The Soviet Industrialization Debate, 1924-1928, at xvi (Harvard U Press, 1960).

54. Soviel Encyclopedia at 672 (cited in note 12); Wieczynski, Modern Encyclopedia at 188 (cited in note 7). See Keith Smith, Soviet Industrialization and Soviet Maturity 8-21 (Routeledge \& Kegan Paul, 1986) (general discussions of NEP); Edward Hallett Carr \& Robert W. Davies, Foundations of a Planned Economy 1926-1929 (MacMillan, 1969).

55. Soviet Encyclopedia at 672 (cited in note 12); Wieczynski, Modern Encyclopedia at 188 (cited in note 7).

56. Wieczynski, Modern Encyclopedia at 188 (cited in note 7).

57. Representatives of the commodity exchanges met with the government and recommended ways to improve the climate for free trade. Ball, The Nepmen at $80-81$ (cited in note 40). Those recommendations were not adopted.

58. 26 Great Soviet Encyclopedia 38 (MacMillan, 1981). See also Alec Nove, Studies in Economics and Russia 173 (St. Martin's Press, 1990) (description of "commodity fetishism").

59. 26 Great Soviet Encyclopedia at 38 (cited in note 58). 
organization of the economy begins with the liquidation of the market. Indeed, to the Marxist, the market, the arena for the exchange of commodities, is the heart of the capitalist economy .... The choking off of the free exchange of products and services, therefore, constituted a central objective of Bolshevik economic policy."60 The assassination attempt of Lenin just after he visited the Moscow commodity exchange ${ }^{61}$ may have further lessened the popularity of the exchanges with his government. Operation of the commodity exchanges was abolished in $1930,{ }^{62}$ as were the fairs, including the one at Nizhnii Novgorod.63

\section{Central Planning}

Under Stalin, the Soviet Union found a centrally planned economy preferable to a market economy, even a mixed one like NEP. ${ }^{64}$ It was Stalin's view that industrialization was needed to overcome deficiencies in the Soviet economy, which was some thirty to fifty years behind the industrial nations. ${ }^{65}$ Stalin also sought to increase grain supplies from the peasants to feed the urban workers. Thus began the great collectivization effort. ${ }^{66}$

The peasants resisted collectivization by once again decreasing their production. ${ }^{67}$ Stalin fought back by imposing compulsory procurement of agricultural products, ${ }^{68}$ much of which was used for export. ${ }^{69}$ "Grain was seized from peasants who refused to sell at low state prices, and many local markets were closed-all of which amounted to a repeal of NEP's most fundamental principle, the right of peasants to sell grain freely. ${ }^{70}$ "Private

60. Richard Pipes, The Russian Revolution 698 (Alfred A. Knopf, Inc., 1990).

61. Id at 806. The government was also alarmed by the fact that Nepmen were interfering with the State's grain collection efforts. The Nepmen were offering higher prices for grain and were using scarce transportation facilities in their activities. Ball, The Nepmen at 256-57 (cited in note 40).

These were not the only economic concerns of Lenin and his government. For example, the "social division of labor" in capitalist societies seemed to be a matter of particular criticism. See generally Vladimir I. Lenin The Development of Capitalism in Russia 39 (Progress Publishers, 1977); Vladimir I. Lenin, On the So-Called Market Question 26 (Progress Publishers, 3rd print 1976); Lyashchenko, History of the National Economy of Russia to the 1917 Revolution 496 (cited in note 8).

62. Wieczynski, Modern Encyclopedia at 188 (cited in note 7). "[A]s a result of the liquidation of the multilayered features of the country's economy and the strengthening of planning principles, exchanges became unnecessary, and so they were closed." Soviet Encyclopedia at 672 (cited in note 12).

63. Ball, The Nepmen at 125 (cited in note 40 ).

64. Stalin asserted that there were only two alternatives: "Either back-to capitalism, or forward-to Socialism. There is no third way, nor can there be." E. Yaroslavsky, Landmarks in the Life of Stalin 152 (Lawrence \& Wishart, Ltd., 1942).

65. Holzman, The Soviet Economy at 9-10 (cited in note 51).

66. See generally Dobbert, Red Economics at 124-33 (cited in note 51 ).

67. Id at 128-33.

68. Roger Munting, The Economic Development of the USSR 98 (St. Martin's Press, 1982); Michal Mirski, The Mixed Economy NEP and its Lot 213-30 (Rosenkilde \& Bagger, 1984). Using a criminal code provision that prohibited speculative hoarding of grain, police searched villages for grain. "Stalin himself led the campaign, spending three weeks in the Urals and Siberia in early 1928," Bleaney, Do Socialist Economics Work? at 10 (cited in note 53).

69. During the Stalin era, "the Soviets exported grain to acquire badly needed foreign exchange even in periods of poor crops and insufficient availability of grain for human consumption." $M$. M. Kostecki, The Soviet Impact on Commodity Markets 202 (St. Martin's Press, 1984).

70. Ball, The Nepman at 97 (cited in note 40 ). 
trade ... became a crime, punished as 'speculation' with a sentence of five to ten years in a labor camp and loss of property." 71

This collectivization resulted in famine attended by mass murders and the uprooting of the peasantry. Although the Soviets managed to advance their industrial base, ${ }^{72}$ millions died in this unsuccessful social experiment, ${ }^{73}$ and much of the rest of the population lived off government rations. ${ }^{74}$ Nonetheless, Stalin continued his "terror" and purges through the 1930s, arresting more millions who were put to forced labor, death, or both. ${ }^{75}$

\section{World War II and Beyond}

The Soviet Union was unable to avoid war through its non-aggression pact with Germany, ${ }^{76}$ although it was able to harness its economy to help defeat the Nazi war machine during World War II. ${ }^{77}$ The Soviets suffered unbelievable casualties and atrocities during that conflict, as well as deep incursions into their territory. ${ }^{78}$ They fought back with vicious determination at a time when the other Allies were still converting their economies to a wartime footing. ${ }^{79}$

After the Nazi defeat, the Soviet economy recovered to pre-war levels within five years ${ }^{80}$ and continued to expand rapidly for several more years, ${ }^{81}$

71. Id at 128 .

72. Harry G. Shaffer, ed, The Soviet System in Theory and Practice, Western and Soviet Views 334-35 (Frederick Ungar, 1984).

73. Ronald Hingley, Joseph Stalin: Man and Legend 204-05 (McGraw Hill, 1974); see also Mirski, The Mixed Economy NEP and its Lot at 213-30 (cited in note 68); Holzman, The Soviet Economy at 10 (cited in note 51 ).

74. Ball, The Nepman at $124-25$ (cited in note 40).

75. See Ian Grey, Stalin, Man of History 265-92 (Doubleday, 1979); Robert Conquest, The Great Terror, A Reassessment (Oxford U Press, 1990).

76. See H. Montgomery Hyde, Stalin: The History of a Dictator 379-435 (Farrar, Straus \& Giroux, $1971)$.

77. Even in war operations Stalin could not refrain from centralized micro-management. Stanley Weintraub, Long Day's Journey Into War 76-77 (Dutton, 1991); Robert H. McNeal, Stalin: Man and Ruler 242 (MacMillan, 1988).

78. Martin Gilbert, The Second World War 198-258 (Weidenfeld \& Nicolson, 1989); Christopher Duffey, Red Storm on the Reich (MacMillan, 1991); Bleaney, Do Socialist Economics Work? at 18 (cited in note 53).

79. The Soviet Union was assisted in its war effort by the other Allies:

During the Soviet-German War the United States, Britain and Canada sent Russia 10,000 tanks, 14,500 planes, 10,000 cannon, more than two million tons of food, hundreds of ships, nearly half a million trucks, half a million tons of nonferrous metals, enough cloth for three million uniforms, and three billion dollars worth of machinery including several complete factories.

Ellsworth Raymond, The Soviet State 419 (New York U Press, 2d ed 1978).

80. Grain relief and other aspects of the Marshall Plan played a significant role in the post-war recovery of Western Europe. Not surprisingly, however, the Soviet Union refused to participate in that program because the Marshall plan was formulated to stop communist political advances that were occurring in Europe as a result of the hardships and shortages that followed the war. Michael $\mathrm{J}$. Hogan, The Marshall Plan, America, Britain, and the Reconstruction of Western Europe, 1947-1952, at 43-45, 51-53 (Cambridge U Press, 1987); see also Charles S. Maier \& Gunter Bischof, eds, The Marshall Plan and Germany 49-70 (St. Martin's Press, 1991); Henry Pelling, Britain and the Marshall Plan 7-27 (MacMillan, 1988); Forrest C. Pogue, George C. Marshall, Statesman 1945-1959, at 197-257 (Viking Press, 1987); Robert Payne, General Marshall 295-98 (Windmill Press, 1952). Even the suggestion of Soviet participation in the Marshall Plan had, however, given rise to rightwing-based calls of treason 
guided by long-range economic plans that set economic production goals for the entire country. GOSPLAN, the State Planning Committee, formulated these five-year and other development plans; the first was implemented in 1928. These plans were carried out through government agencies such as Gosnab and, much later, by RAPO in the agriculture sector. ${ }^{\mathbf{8 2}}$

As a result of its military successes, the Soviet Union emerged from World War II as a world power. However, Soviet military power, later achievements in space, and the government's strict control of information, masked serious flaws in the concept of central planning. By the 1950s, the Soviet Union's economy had begun to slow from its post-war regeneration. ${ }^{83}$ In addition, the early successes with industrial recovery under central planning were unmatched in the farm sector: Stalin's collectivization had not worked, and the condition of agriculture production continued to be "deplorable." 84 Consumer concerns were also given short shrift. ${ }^{85}$

Several efforts were made to improve agricultural production after Stalin's death. ${ }^{86}$ For example, Nikita Kruschchev sought to cultivate the "virgin lands" in the east and in Kazakhstan. ${ }^{87}$ The Soviets also began a massive effort to increase the educational level of their people, and they continued to seek to expand industrial production. ${ }^{88}$ Still, however, the downward trend continued. Moreover, by the 1960s, the Soviet economy had become too complex for central management. ${ }^{89}$ Soviet economists then began to consider introducing elements of capitalism, such as those used during the NEP period, into the economy. ${ }^{90}$

In 1965, Premier Kosygin announced a new set of economic reforms, including the introduction of a profit motive into state enterprises. ${ }^{91}$ This tepid approach to capitalism, however, failed to correct the flaws of central

in the United States. See Joseph R. McCarthy, America's Retreat From Victory, The Story of George Catlett Marshall 140 (Devin-Adair Co., 1951).

81. Holzman, The Soviet Economy at 11 (cited in note 51).

82. See Alec Nove, The Soviet Economic System 21-26, 129 (Allen \& Unwin, 3d ed 1986); Felicity Barringer, Wide Bartering Keeps Leningrad Going, NY Times Al col 3 (Sept 4, 1991); Ned Temko, Sowing Reform in Soviet Agriculture, Christian Science Monitor 1 (Aug 25, 1983).

83. Holzman, The Soviet Economy at 12 (cited in note 51).

84. Nove, The Soviet Economic System at 114-16 (cited in note 82).

85. See generally Raymond, The Soviet State at 134 (cited in note 79).

86. Id at $163-64$.

87. Ronald J. Hill, The Soviet Union, Politics, Economics and Society from Lenin to Gorbachew 26 (Pinter Publishers, 1989); Bleaney, Do Socialist Economics Work? at 24 (cited in note 53). The virgin lands campaign was followed by a "maize" campaign which sought to increase the production of corn. Raymond Hutchings, Soviet Economic Development 121 (New York U Press, 2d ed 1971). These and other schemes all proved to be failures. Raymond, The Soviet State at 163 (cited in note 79).

88. Holzman, The Soviet Economy at 11-12 (cited in note 51).

89. Shaffer, The Soviet System at 338-39 (cited in note 72).

90. Dooling, The Legacy of NEP at 42-43 (cited in note 39).

91. Evsey D. Domar, Capitalism, Socialism and Serfdom xvi (Cambridge U Press, 1989). General Secretary Brezhnev himself proposed various agricultural reforms, including stable prices and financial incentives. Paul J. Murphy, Brezhnev, Soviet Politician 261 (McFarland \& Co., 1981). Brezhnev also observed that when prices went up deliveries increased and vice versa. George W. Breslauer, Khrushchev and Brezhnev as Leaders: Building Authority in Soviet Politics 145 (George, Allen \& Unwin, 1982). 
planning. By the mid-1970s, even a casual visitor to the Soviet Union could not fail to observe that something was seriously wrong. Consumer shortages were endemic and housing was often squalid and crowded. The contrast between the rebuilt economies of post-war Europe (only a short plane ride away) and the Soviet Union was observable and palpable. ${ }^{92}$

This downward course continued into the 1980 s. $^{93}$ It took perestroika and glasnost to awaken the Soviet public. ${ }^{94}$ Unfortunately, many of the restructuring efforts were impractical or still retained communist concepts of unified actions. For example, President Gorbachev advocated a brigade system of workers for collective farms, with payments based on results. Socialist peer pressure in the brigades, it was assumed, would increase productivity. ${ }^{95}$ Gorbachev also proposed a variation of the food tax used by Lenin during the NEP period: state production quotas were set and the collectives were allowed to sell the excess. Later, Gorbachev authorized enormous price increases for grain produced in excess of the quotas. ${ }^{96}$ The Communist Party Central Committee also adopted President Gorbachev's proposals for land leasing arrangements in the agricultural sector. ${ }^{97} \mathrm{He}$ was, however, forced to abandon any thoughts of breaking up the collective farms, ${ }^{98}$ and agricultural production continued to be abysmal. ${ }^{99}$

Communism and central planning simply did not work. Sixty years of central planning had demonstrated that the best that could be expected from

92. Brezhnev had unsuccessfully sought to arrest the decline by launching detente and increasing East-West trade through expanded grain purchases. Hill, Soviet Union, Politics, Economics and Society from Lenin to Gorbachev at 28 (cited in note 87). Chernenko, in turn, proposed a massive project to reclaim land that was too wet for production and irrigating land that was too dry. Thomas G. Butson, Gorbacher, A Biography 137-38 (Stein \& Day, 1986). This too failed.

93. See Holzman, The Soviet Economy at 54 (cited in note 51).

94. See Harley D. Balzer, Five Years That Shook the World, Gorbachev's Unfinished Revolution (Westview Press, 1991); Gail Sheehy, The Man Who Changed the World, The Lives of Mikhail S. Gorbachev (Harper Collins Publishers, 1990); David North, Perestroika Versus Socialism, Stalinism and the Restoration of Capitalism in the USSR (Labor Publications, 1989) (discussion of glasnost and perestroika).

95. J. L. Porket, Work, Employment and Unemployment in the Soviet Union 130-32 (St. Martin's Press, 1989). Such brigades were previously used in the Soviet Union to collect taxes and to seize the property of Nepmen and "hoarders." Ball, The Nepmen at 122-123 (cited in note 40).

96. Zhores Medvedev, Gorbachev 249-50, 256 (Basil Blackwell, 1986). See also Robert C. Tucker, The Last Leninist, NY Times E9 col 2 (Dec 29, 1991) (discussion of Gorbachev's inability to understand that central control had to be abandoned).

97. See Olimpiad S. Ioffe, Gorbachev's Economic Dilemma: An Insider's View 228-45 (Merrill/Magnus, 1989).

98. Dusko Doder \& Louise Branson, Gorbachev: Heretic in the Kremlin 362-63 (Viking Press, 1990).

Gorbachev also proposed that the incomes of the collectives be tied to their production, but this did not change their essential socialist nature. Donald Morrison, ed, Mikhail S. Gorbachev, An Intimate Biography 158-59 (Time, Inc., 1988).

99. Francis X. Clines, Delay in Election Urged by Yeltsin, NY Times A3 col 1 (Oct 17, 1991) (20\% drop in Soviet grain harvest predicted); Francis X. Clines, 10 Soviet Republics Agree to Coordinate Food Supply, NY Times A5 col 1 (Sept 17, 1991) (food production in the Soviet Union has been dropping at an annual rate of $10 \%$ to $12 \%$ ).

Collective and state farm workers have been allowed to farm "private" plots. There are also an estimated 30,000 farms that are the principal source of income of the individuals occupying them. This "private" farming, as limited as it is, is now responsible for a substantial percentage of overall agricultural production in the republics. Russia's Entrepreneurs: The Wild East, The Economist 40 Jan 4, 1992). 
such an economy was "shoddy goods, chronic shortages and exploding inflation." 100 The production and distribution of commodities was simply too centralized. ${ }^{101}$ For example, "[o]ne recent Soviet study, which dealt with almost 6,000 different products, found that three-quarters of them were supplied by just one producer." 102 An estimated 18 million bureaucrats in the Soviet system were trying to substitute for a market. "The results: 234 out of 277 basic consumer goods . . are absent from the shelves . . ."10s Moreover, "[e]ven before the failed coup ... inadequate supplies and incompetent distribution were fueling social tension, ethnic strife and a devastating economic depression." 104

\section{III}

\section{The Soviet Union and Commodity Markets in the United States}

The abolition of the exchanges at the conclusion of NEP did not stop the Soviet government from using the commodity exchanges in the United States to market grain. In 1930, apparently as part of Stalin's forced grain procurements from the peasantry, ${ }^{105}$ the All-Russian Textile Syndicate traded heavily on the Chicago Board of Trade over a four day period. ${ }^{106}$ These "short" sales of almost eight million bushels of wheat were initiated by "orders out of Moscow."107 The sales involved over ten percent of the trading on the Chicago Board of Trade. The Soviet sales forced market prices down, causing a great deal of concern in Chicago. ${ }^{108}$ The Chicago Board of Trade passed a resolution stating that "the selling of futures upon our exchanges by any foreign government is a new development of commerce of seriously objectionable character and it must be brought to an end." 109

A congressional investigation later determined that the Soviet government had not intended to depress grain prices. ${ }^{110}$ The Soviets had been out of international markets for some time, and could not contract their grain sales for forward or deferred delivery. Consequently, they were left in the undesirable position of having to load their grain on ships for transport to

100. Peter Passell, A Centerless Soviet Economy May Not Be So Bad, Western Experts Say, NY Times A9 col 1 (Sept 5, 1991).

101. "Gigantic enterprises now produce more than 90 percent of the Soviet Union's sewing machines, forklifts, diesel locomotives, freezers, washing machines and concrete mixers." Id.

102. Flight From the Kremlin, The Economist 13-14 (Aug 31, 1991).

103. Boettke, Political Economy at xv (cited in note 46).

104. Craig Forman, Freedom's Perils: Soviet Economy Holds Potential for Disaster as the Union Weakens, Wall St J Al col 6 (Sept 4, 1991).

105. See note 69 and accompanying text.

106. Report of the Chief of the Grain Futures Administration, U.S. Dept of Agriculture 6 (1930) ("1930 GFA Report").

107. Agriculture Department Appropriation Bill for 1932; Hearing before a Subcommittee of the House Committee on Appropriations, 71 st Cong, 3rd Sess 585-86 (1930) ("1932 Hearings").

108. Id at 586.

109. 1930 GFA Report at 6 (cited in note 106)

110. Arthur G. Peterson, Futures Trading With Particular Reference to Agricultural Commodities 7 Agricultural History 68, 78 (Agric History Society, 1933). 
market at whatever price was available. The Soviets knew that when this was made known to the world prices for grain would drop drastically, and they would receive substantially reduced prices for their grain. To avoid that result, the Soviets sold short on the Chicago markets, thereby earning a profit when grain prices dropped. Those profits were then used to offset the reduced prices they received for their sales of the actual grain. ${ }^{111}$ This, as will be discussed below, is simply a form of "hedging," which is a principal purpose of commodity exchanges in the United States. ${ }^{112}$

A House committee originally recommended that legislation be passed to prohibit such short sales by the Soviet Union and other foreign governments. Although that legislation did not pass, ${ }^{13}$ the whole episode did nothing to enhance the popularity of commodity exchanges with the Soviet government. In fact, the exchanges became a favorite whipping boy for Soviet ideology. Soviet texts, for example, charged that government officials in the United States "play through their dummies on the exchange and make enormous profits." 114 The exchanges in the United States were also said to be operating "[u]nder the domination of monopolistic prices ..." which lessens their effectiveness. ${ }^{115}$ Nevertheless, the Soviets continued to deal in the world's

111. Id at 78 .

112. See note 147 and accompanying text.

113. Commodity Short Selling, HR Rep No 1551, 72d Cong, 1st Sess 2 (1932).

114. Soviet Encyclopedia at 672 (cited in note 12). Evidence to support such claims is scanty. In 1947, Harold Stassen, then a viable presidential candidate, charged that Truman Administration officials had profited from inside information on large price increases occurring on the futures markets. Congress then passed a joint resolution requiring the publication of the names of traders during that period. President Truman was deeply embarrassed to discover that his personal physician was among those profiting. Even more serious was the trading of a special assistant to the Secretary of the Army. His profits totaled over $\$ 900,000$. That official denied using inside information, but he eventually resigned after Stassen charged that his "sense of right and wrong is not fully developed." Robert J. Donovan, Confict and Crisis 349-50 (W.W. Norton \& Co., 1977). See also Roscoe Drummond, The Case for Stassen, Life Magazine 39, 48 (March 1, 1948) (pictorial of Stassen's dramatic revelations of this event). Truman denied all knowledge of the trading and continued to defend his physician. Public Papers of the Presidents: Harry S. Truman - 1947, at 508, 512 13, 536-37 (US Govt Printing Office, 1963).

A select committee of Congress also found that a leak of government commodity purchasing policies had occurred between 1946 and 1948 , and that there had been a large amount of speculation in lard just prior to a government announcement affecting that commodity. The committee found that two government officials had traded in lard during that period. Final Report on Commodity Transactions, HR Rep No 2472, 80th Cong, 2d Sess 12-15 (1948).

In addition, Senator Joseph McCarthy used campaign contributions to speculate in soybean futures contracts. Curt Gentry, J. Edgar Hoover, The Man and the Secrets 432 (W.W. Norton \& Co., 1991). More recently, there have been charges that market-moving information from the weather service has been leaked to commodity futures traders. Jeffrey Taylor, U.S. Looks Into Claim of 'Leak' of Market-Moving Weather Data, Wall St J Cl col 4 (July 16, 1991).

115. Soviet Encyclopedia at 672 (cited in note 12). The evidence here is also somewhat lacking. In fact, the commodity futures markets are highly competitive. See Thomas A. Hieronymus, Economics of Futures Trading 95 (Commodity Research Bureau, 1977) ("futures markets closely approach the conditions of pure competition"). The commodity markets, however, are not perfect. They are susceptible to manipulation and various trading abuses. 7 USC $\S 5$ (1988). See generally David Greising \& Laurie Morse, Brokers, Bagmen, E Moles (John Wiley \& Sons, Inc., 1991); Jerry W. Markham, Manipulation of Commodity Futures Prices - The Unprosecutable Crime, 8 Yale J Reg 281 (1991). The market manipulation has been held to violate the antitrust laws. See, for example, Board of Trade $v$ United States, 246 US 231 (1918); United States v Patten, 226 US 525 (1913); Minpeco, S.A. v Hunt, 
commodity markets through foreign trading organizations such as Raznoimport and Technoexport (nickel), Sojuzneftexport (oil), Prodintorg (foodstuffs), Vneshekonbank (gold), ${ }^{116}$ and Exportkhleb (grains). ${ }^{17}$

Despite lagging production, the Soviet Union became a net exporter of grain during much of the 1950s and 1960s; it was even viewed to be a potential competitor of the United States in world markets. ${ }^{118}$ From 19631966, however, the Soviet Union became a net importer as a result of "disastrous harvests."119 In 1963, to improve tense relations, President Kennedy authorized the sale of four million tons of wheat and flour to the Soviets, and further sales were made in 1964 and $1965 .^{120}$ The Soviets thereafter returned to their export role for a brief period. In the $1970 \mathrm{~s}$ the Soviet Union became a "consistent net grain importer"'121 because the Soviet planners sought to add more pork and poultry to the Soviet diet, thus requiring more grain for livestock feeding. ${ }^{122}$

American grain producers were all too anxious to accommodate the Soviet import program. They approached the Nixon administration to ease restrictions that would inhibit the Soviet purchases. Nixon, under political pressure to support such sales, accommodated them. ${ }^{123}$ Specifically, he announced that grain exports to the Soviet Union (and to the People's Republic of China) would no longer be subject to the Export Control Act's ${ }^{124}$ validated licensing requirements. ${ }^{125}$ Nixon also rescinded the American flag shipping requirement for grain exports. ${ }^{126}$

The Soviets responded in kind. In November of 1971, they purchased some three million tons of U.S. grain. ${ }^{127}$ In 1972, they purchased several times that amount, as much as twenty-five percent of the U.S. wheat crop. ${ }^{128}$ This caused large increases in consumer prices in the United States and

[1987-1990 Transfer Binder] Comm Fut L Rptr (CCH) ๆ24,538 (SD NY 1989); Comment, Price Manipulation in the Commodity Futures Market: A Re-Examination of the Justifications for Simultaneous Causes of Action Under the CEA and the Sherman Act, 34 UCLA L Rev 1305 (1987) (authored by John Kern).

116. See Neil Behrmann, Uncertainty Over Future of Soviet Union Stirs Fears Among Commodity Dealers, Wall St J B3 col 2 (Sept 3, 1991).

117. Kostecki, The Soviet Impact on Commodity Markets at 194 (cited in note 69).

118. Id at 194-95.

119. Morgan, Merchants of Grain at 211 (cited in note 44); Kostecki, The Soviet Impact on Commodity Markets at 194 (cited in note 69).

120. Morgan, Merchants of Grain at 162-71 (cited in note 44).

121. Kostecki, The Soviet Impact on Commodity Markets at 195 (cited in note 69) ("Soviet grain imports markedly exceeded grain exports.").

122. Holzman, The Soviet Economy at 34 (cited in note 51); Morgan, Merchants of Grain at 192-93 (cited in note 44).

123. Morgan, Merchants of Grain at 196-97 (cited in note 44).

124. The Export Control Act was replaced by the Export Administration Act of 1979, 50 USC $\S$ 2401-2420. The latter Act expired on September 30, 1990 but was extended by Presidential Order under the International Emergency Economic Powers Act. 50 USC $\S 11701$ et seq.

125. Russian Grain Transactions Hearings before the Senate Permanent Subcommittee on Investigations of the Committee on Government Operations, Part 1, 93d Cong, 1st Sess 8 (1973) ("Hearings on Russian Grain Transactions").

126. Id. This provision had required that $50 \%$ of all U.S. grain exports be transported in American-flagged ships. Id.

127. Id.

128. Id at 2 . 
resulted in a political maelstrom. ${ }^{129}$ Indeed, the " 'grain robbery' of 1972 was one of those economic events that, like the OPEC oil embargo the following year or the repeal of the Corn Laws more than a century earlier, can truly be said to have changed the world."130

Initially, the Soviet grain purchases were "erratic," but they began to institutionalize their purchases through long-term contracts. ${ }^{131}$ On January 4, 1980, however, President Carter embargoed some seventeen million tons of grain that were destined for the Soviet Union as a protest of the Soviet invasion of Afghanistan. ${ }^{132}$ Carter's action also resulted in a brief suspension of grain trading on all U.S. commodity exchanges. ${ }^{133}$ Although the Soviets were able to obtain grain from alternate sources, ${ }^{134}$ economic conditions in the Soviet Union continued the downward slide that eventually led to breakdown.

\section{IV}

\section{Development of Commodity Exchanges in the United States}

The purchase and sale of commodities, by barter or otherwise, is as old as humanity. ${ }^{135}$ Futures trading in various forms has been traced to 2000 B.C.

129. Stephen E. Ambrose, Nixon: Ruin and Recovery 155 (Simon \& Schuster, 1991). The Soviet grain sales not only increased consumer prices, but they also resulted in increased export subsidies totaling some $\$ 300$ million. Hearings on Russian Grain Transactions at 3 (cited in note 125).

130. Morgan, Merchants of Grain at 172 (cited in note 44).

131. Kostecki, The Soviet Impact on Commodity Markets at 198-99 (cited in note 69).

132. Futures Trading Act of 1982, HR Rep No 565, 97th Cong, 2d Sess 59-60 (1982). See Jeffrey Antevil, Reuters, Lid., (Nexis) (Jan 7, 1980). This was the first time that grain had been used as a political weapon, and the president's action was exceedingly unpopular with U.S. farmers. Geoffrey Atkins, Reuters, Ltd., (Nexis) (May 4,.1980). To placate that very important political sector, President Carter subsequently announced that the federal government would spend over $\$ 2$ billion on grain to replace the Soviet sales that were embargoed. James Vicini, Reuters, Ltd., (NExis) (Jan 7 , 1980); U.S. to Buy Soviet Grain Contracts, Facts on File World News Digest (Nexis) (Jan 11, 1980).

The embargo was subsequently lifted by President Reagan. Lee Lescaze, Reagan to Lift Grain Embargo Today; President Will Lift Embargo on Grain, Washinton Post Al (April 24, 1981); William Robbins, Farmers Elated Over End to Curb on Grain for Soviets, NY Times A18 col 2 (April 30, 1981). His administration also entered into a five year agreement with the Soviets that provided for the sale of at least nine million tons of grain annually. The United States government agreed that there would be no further embargoes during the life of the agreement. Clyde H. Farnsworth, U.S. Vow on Grain Delivery, NY Times D4 col 1 (Aug 26, 1983).

Congress later acted to restrict the ability of future presidents to embargo grain under contract. See 7 USC \$612c-3. President Reagan threatened to veto this provision but relented when it became clear that the "national emergency" exceptions to the restrictive provisions of the bill still allowed the president broad discretion to impose an embargo. H. J. Maidenberg, Options on Farm Products, NY Times DI0 col 3 (Dec 20, 1982).

133. Commodity Futures Trading Commission-The First Ten Years 35 (Commodity Futures Trading Commission, 1985).

134. Kostecki, The Soviet Impact on Commodity Markets at 199 (cited in note 69).

135. As one article notes:

Commodity markets are not recent in origin. Regulated commodity markets existed in China, Egypt, Arabia and India as early as 1200 B.C. However, modern day exchanges dealing in commodity futures can more readily be traced to the medieval trade fairs of Twelfth Century Europe.

Ed Jones \& John F. Cook, II, The Commodity Futures Trading Commission Act of 1974, 5 Memphis St U L Rev 457, 458 (1975) ("Commodity Futures") (footnote omitted). See also Note, Ernst \& Ernst v 
on Bahrein Island, ${ }^{136}$ as well as to Greco-Roman times. ${ }^{137}$ In Japan, futures were traded in rice "tickets" in the early $1700 \mathrm{~s}, 138$ and a primitive form of futures trading took place in America in the 1790s. ${ }^{139}$ Talleyrand was among those participating in the latter market during his exile from the French Revolution. ${ }^{140}$ However, the modern mechanisms and flexible contractual arrangements in the United States for pricing and future sale of commodities is a phenomenon of the nineteenth century.

The westward expansion in the United States that accelerated throughout the nineteenth century created massive growth in agriculture, particularly in grains such as wheat, corn, and, later, soybeans. There was, however, no efficient marketing mechanism for those grains; available storage and transportation facilities were not sufficiently developed to disburse the grain to other market centers in an orderly fashion, particularly when much of the rail and water transportation was blocked or reduced by winter weather. ${ }^{141} \mathrm{At}$ the end of a crop year, farmers would bring their produce to the market, which then would be inundated with grain. Prices dropped, and grain would be left to rot in the streets. Later, supplies would grow scarce, wreaking havoc on processors who needed the grain for their operations. ${ }^{142}$

To even out this annual boom-and-bust cycle, farmers entered into socalled "to-arrive" or "forward" contracts that provided for delivery at future dates. ${ }^{143}$ In other words, these contracts provided for delivery of the grain at a time in the future. This helped stabilize the grain market because farmers could defer their deliveries and avoid flooding the market. The grain could be stored in elevators until the appointed delivery date approached. Forward contracts also assured producers of a fixed price for grain, and it allowed shippers, processors, and consumers to receive grain supplies in an orderly and efficient manner as they were needed. ${ }^{144}$

The forward contract evolved on the Chicago Board of Trade in the 1860s into the "futures" contract, which in essence is a forward contract with standardized terms. The terms that were standardized included delivery dates, the quantity of the commodity, and its grade. The only term negotiated

Hochfelder as Applied to Commodities Fraud: No Intent Required, 79 Ky L J 369, 373 (1990-91) (authored by Harry B. Borders).

136. Futures Industry Association, An Introduction to the Futures Markets 2 (1984).

137. Chicago Board of Trade Commodity Trading Manual 1 (1989) ("Commodity Trading Manual").

138. Id at 2 .

139. Simon Schama, Citizens: A Chronicle of the French Revolution 868 (Alfred A. Knopf, 1989).

140. Id.

141. William Cronon, Nature's Metropolis: Chicago and the Great West 123-25 (W.W. Norton, 1991); Commodity Trading Manual at 3-4 (cited in note 137).

142. Frederick F. Horn \& Victor W. Farah, Trading in Commodity Futures 5 (NY Inst of Finance, 2d ed 1979).

143. These contracts were initially called "to-arrive" contracts. George Hoffman, Future Trading Upon Organized Commodity Markets in the United States 29 (U of Pennsylvania Press, 1932).

144. Cronon, Nature's Metropolis at 123-25 (cited in note 141); Commodity Trading Manual at 3-4 (cited in note 137); Hieronymus, Economics of Futures Trading at 72-76 (cited in note 115); Jones \& Cook, Commodity Futures at 459 (cited in note 135). 
was the price. ${ }^{145}$ Standardization made futures contracts fungible, which allowed them to be offset or liquidated before the delivery deadline, meaning that the purchaser or seller no longer needed to own or expect to take delivery of the commodity. This led to the development of an organized market where futures contracts could be offset as prices changed, allowing the realization of profit or loss without actually taking delivery of the grain. ${ }^{146}$

The creation of a futures market had important economic consequences, such as the use of futures contracts for hedging. For example, a wheat farmer satisfied with existing prices, but concerned that wheat prices might drop before the grain was harvested, could sell wheat futures short on a futures exchange. If prices dropped, the farmer would receive profits on the futures contracts that could be used to offset the losses on the actual grain when it was marketed. If prices increased, the farmer would receive increased profits on the actual grain, but those profits would be offset by the losses on the short futures positions. This hedging function operates much like an insurance policy. ${ }^{147}$

Futures contracts also serve a price discovery function. A farmer in Iowa, for example, can look at prices on the Chicago Board of Trade printed in the local newspaper to value his crops and later his livestock. Based on those prices, he can determine what crops should be planted or when livestock should be sold. ${ }^{148}$ However, futures contracts encourage speculation because traders can speculate in price change differences without owning the actual commodity. This may be deemed undesirable if such speculation distorts prices. $^{149}$ Nevertheless, speculation is viewed as necessary for the efficient

145. Cronon, Nature's Metropolis at 125-32 (cited in note 141); 2 FTC, Report on the Grain Trade 10809 (1920); Commodity Trading Manual at 5-6 (cited in note 137).

146. Jones \& Cook, Commodity Futures at 460 (cited in note 135).

147. FTC, Grain Exporters at 34-35 (cited in note 44); Wendy Collins Perdue, Manipulation of Futures Markets: Redefining the Offense, 56 Fordham L Rev 345, 349-52 (1987); Note, Federal Regulation of Commodity Futures Trading, 60 Yale L J 822, 825-30 (1951); Cargill Inc. v Hardin, 452 F2d 1154, 1158 (8th Cir 1971); Volkart Brothers, Inc. v Freeman, 311 F2d 52 (5th Cir 1962).

The description of hedging in the text is grossly oversimplified. Among other things, a hedger must have financing available to meet margin calls, which may be substantial. Margin funds will later be recovered if the hedge is effective. But the cost of those funds may be significant, and the value of the hedge may be lost if margin funds are not available. Indeed, large out-of-pocket losses may occur in such an event. Further problems may occur because of differences in the quality of the grain being hedged and that of the grain under the futures contract, causing pricing disparities. There may also be basic pricing differences because of the different locations between the farmers' grain and the grain that is to be delivered under the futures contract. In addition, delivery is rarely taken on a futures contract. Rather, the farmer will generally offset the futures contracts and sell the actual grain separately, sometimes causing delicate timing problems. Alternatively, the farmer can engage in a complicated "exchange of futures for physicals" transaction. See note 157; Horn \& Farah, Trading in Commodity Futures at 180-205 (cited in note 142); Commodity Trading Manual at 61-80 (cited in note 137); Minpeco, S.A. v ContiCommodity Services, Inc., 676 F Supp 486 (SD NY 1987); Minpeco, S.A. v Hunt, 686 F Supp 420, 425 (SD NY 1988) (discussion of losses claimed by hedger). See note 215 for a discussion of margin requirements for futures contracts.

148. 120 Cong Rec 34,999 (Oct 10, 1974) (statement of Senator Humphrey) (futures markets allow prices to be determined competitively).

149. The Commodity Exchange Act of 1936 was adopted by Congress to combat the effects of excessive speculation and manipulation. 7 USC $\$ \S 1$ et seq. In 1974, as a result of the "Great Grain Robbery" discussed in notes 123-30 and accompanying text, and other events, the Commodity Exchange Act was substantially amended. Commodity Futures Trading Commission Act of 1974, 
operation of the futures markets. Speculators add liquidity to the market and they displace the risks of the hedgers. Non-excessive speculation in the markets is permitted, if not encouraged, ${ }^{150}$ because "a sound futures market tends to reduce retail prices of the underlying commodities."151

Although the futures exchanges play an integral role in the distribution of commodities in the United States, they are not the only components in that process. ${ }^{152}$ Commodities are accumulated and dispersed through a vast infrastructure of silos and grain elevators at local levels and by well-developed interstate and international transportation systems. ${ }^{153}$ This includes the railroads, waterways, and, particularly desirable for smaller perishable crops, an interstate and local highway system connecting most rural areas with the cities. ${ }^{154}$ Complementing this infrastructure is a sophisticated system of middlemen, who purchase crops from producers and redistribute them to processors and consumers. An excellent example of how the distribution system works is the manner in which foreign grain sales are effected. To illustrate, in instances where there is a large demand for grain abroad, as in the case of prior Soviet grain purchases, a large grain merchant in the United States can commit to delivery of the grain at a fixed price even though the grain merchant does not own the grain. Instead, the grain merchant purchases grain futures contracts on the Chicago Board of Trade in amounts

Pub L No 93-463, 88 Stat 1389 (1974), codified at 7 USC $\S 4$ a. Futures exchanges in the United States are now loosely regulated under that legislation by the Commodity Futures Trading Commission, a federal agency. See generally Abelardo Lopez Valdez, Modernizing the Regulation of the Commodity Futures Markets, 13 Harv J Leg 35 (1975); Note, The Role of the Commodity Futures Trading Commission Under the Commodity Futures Trading Act of 1974, 73 Mich L Rev 710, 747 (1975).

150. Commodity Futures Trading Commission Act of 1974, HR Rep No 975, 93d Cong, 2d Sess 138 (1974); Commodity Futures Trading Commission, A Study of the Nature, Extent and Effects of Futures Trading by Persons Possessing Material Non-Public Information 14 (Sept 1986).

151. See also Merrill Lynch, Pierce, Fenner E Smith, Inc v Curran, 456 US 353, 390 (1982) (discussion of the role played by speculators in the futures markets); United States $v$ Dial, 757 F2d 163, 165 (7th Cir 1985), cert denied, 474 US 838 (1985) (speculation increases information by providing incentives to forecast supply and demand).

152. Conversely, agricultural commodities are not the only product traded on futures exchanges in the United States. The exchanges have developed a wide array of financial products that are now trading in volumes greater than traditional agricultural futures. These financial futures and related options products are also playing an increasingly important role in the securities markets, as witnessed by the concern they caused during the stock market crash of 1987. See generally The Report of the Presidential Task Force on Market Mechanisms (Jan 1988); Securities and Exchange Commission Division of Market Regulation, The October 1987 Market Break (U.S. Government Printing Office, 1988).

153. The development of the distribution system for grain in pre-revolutionary Russia in some ways paralleled that of the United States. Extending railways to areas with grain surpluses allowed development of an export trade in Russia. "In the past, a good harvest had often meant that grain surpluses had to be distilled, or even left to spoil in barns; now the surplus could be sold at home or abroad." Peter Gatrell, The Tsarist Economy 1850-1917, at 130 (B.T. Batsford, 1986). By the end of the 19 th century, grain constituted about $50 \%$ of Russian exports. Michael T. Florinsky, 2 Russia: $A$ History and Interpretation 939 (MacMillan, 1958).

154. See generally FTC, Grain Exporters at 29 (cited in note 44) (description of World War I era grain handling and loading facilities); David Plowden, The Last of the Old 'Lakers' are Steaming off into History, Smithsonian Magazine 35 (Oct 1991) (description of steamers on the Great Lakes that were used to haul grain); Maury Klein, The Life and Legend of Jay Gould (Johns Hopkins U Press, 1986) (description of some of the machinations that were an unfortunate but integral part of the development of railroads in the United States). 
sufficient to cover the amount of grain that was sold abroad. The grain merchant then begins buying the actual grain from farmers, cooperatives, local elevators, and other grain merchants. ${ }^{155}$ This will cause the price of grain to rise, offsetting the profit on the fixed price contract with the foreign purchaser. The grain merchant is protected, however, by the profits on the futures contracts, which should be responding in the same way as actual grain prices. ${ }^{156}$

As the grain merchant acquires the actual cash grain, the corresponding futures contracts are closed out by offset or otherwise. ${ }^{157}$ At this point, the shipping and storage facilities of the United States provide the mechanism for assembling the actual grain and shipping it to the foreign customer. ${ }^{158}$ This system supplies equal flexibility for the acquisition of grains and other commodities internally. ${ }^{159}$

\section{$\mathrm{V}$ \\ The Market Economy Ideal Emerges in the CIS}

Today there seems to be a broad recognition in the CIS that a market economy and an exchange system for the distribution of commodities such as those in the United States are needed to reverse present economic conditions. As Secretary of State James Baker has observed, however, "[b]uilding democracy and free markets across the Soviet Union is not going to be an easy task after decades of totalitarianism and central planning. The work of freedom will be hard, and the transition will be painful."160 Shortages in food and basic consumer goods are a serious and growing concern in the CIS. The budget deficit and the insolvency of their governments pose further problems. ${ }^{161}$ Indeed, the centrally-planned distribution system has largely collapsed, and there is no functioning market system to replace it. ${ }^{162}$ The CIS

155. See A. Gay Jenson Farms Co. $v$ Cargill, Inc., 309 NW2d 285 (Minn Supp 1981) (description of how parts of this purchasing program work in practice); see also Butler $v$ Bunge Corporation, $329 \mathrm{~F}$ Supp 47 (ND Miss 1971).

156. See Mark J. Powers, Getting Started in Commodity Futures Trading 93-132 (4th ed 1983) (discussion of hedging); see also Note, Federal Regulation of Commodity Futures Trading, 60 Yale L J 822, 825-28 (1951); United States v New York Coffee and Sugar Exchange, 263 US 611 (1924); Cargill Inc. v Hardin, 452 F2d 1154 (8th Cir 1971); United States v Grady, 225 F2d 410, 415 (7th Cir 1955).

157. U.S. Dept Agriculture, Hedging in Grain Futures 29-30 (June 1931) (Circular No 151) (describing alternate method of closing out futures contracts through a complicated exchange of futures for physical commodity transaction); see generally CFTC Div of Trading and Mkts, Report on Exchanges of Futures for Physicals (Oct 1, 1987).

158. There is even an exchange in the United States for acquiring shipping for the export of grain. Michael Abramowitz, Tough Battles for Barge Brokers, Washington Post H1 col 1 (June 9, 1991 ).

159. For an enlightening, as well as entertaining, description of the large grain firms, see Morgan, Merchanis of Grain (cited in note 44). See also Federal Trade Commission, 1-7 Report on the Grain Trade (1921-1926) (exhaustive World War I era review of the grain trade in the United States); FTC, Grain Exporters (cited in note 44) (same).

160. Baker's Remarks: Policy on Soviets, NY Times A12 col 3 (Sept 5, 1991).

161. See generally Leyla Boulton \& Reuter, Cash Crunch for Soviet Public Spending, Fin Times 3 col 1 (Nov 29, 1991); Soviet Debt: A Surplus of Shambles, The Economist 86 (Nov 23, 1991).

162. See Steven Greenhouse, At Moscow's Planning Agency, Many Economists Look for Work, NY Times Al col 2 (Oct 27, 1991) (discussion of the breakdown of Gosplan and Gosnab). See generally James Sterngold, Coup is Linked to Debt Crisis By Soviet Aide, NY Times Al col 1 (Oct 16, 1991). 
must build from scratch the market economy that was destroyed in 1917 , and the CIS has no reservoir of knowledge or experience to help accomplish this transition. ${ }^{163}$

Nevertheless, some steps toward the development of an exchange trading system have already been taken in the CIS. Commodity exchanges are already operating. ${ }^{164}$ The Moscow Commodity Exchange, the first of these efforts, has been functioning for several months as an open market and as an alternative to the state distribution system. It has been emulated by several hundred other exchanges located in numerous cities, including St. Petersburg, Kiev, Novosibirsk, Ryazan, Ekaterinoburg, and Saratov. ${ }^{165}$

163. The confusion surrounding the changes in the political structure of the former Soviet Union will only compound the difficulty of implementing a market economy. See generally Francis $\mathrm{X}$. Clines, Soviet Republics Agree to Create an Economic Union, NY Times A1 col 2 (Oct 12, 1991); Laurie Hays, Ten Republics Agree on Economic Treaty, Wall St J A8 col 3 (Oct 14, 1991); Francis X. Clines, $A$ Gamble With Chaos: Newest Plan by Gorbacheo and Republics Leaves Vexing Economic Riddles Unsolved, NY Times Al col 4 (Sept 3, 1991); Thomas L. Friedman, The U.S. -Soviet Agenda: Moscow's Economic Struggle is Paramount as Baker's Week of Talks Makes Evident, NY Times Al col 4 (Sept 16, 1991); Craig Forman, Another Coup Casualty: All Three Moscow Stocks Sink, Wall St J C1 col 3 (Sept 9, 1991); Francis X. Clines, A Bleak Economy Dims Soviet Hopes for a Free Market, NY Times Al col 6 (Sept 9, 1991).

The Group of Seven (the largest of the industrial countries) has agreed to provide assistance to the CIS in developing economic reform. James Sterngold, 7 Rich Nations to Help Soviets Plan Economy, NY Times Al col 1 (Oct 14, 1991); David Wessel \& Cynthia Owens, G-7 Rejects Debt Deferment for Soviets, Wall St J A8 col 1 (Oct 14, 1991); Gerald F. Seib \& Alan Murray, Herculean Task, IMF Effort to Reform Soviet Economy Runs Many Daunting Risks, Wall St J Al col 6 (Oct 15, 1991).

164. There are a few stock exchanges in the CIS, some of which are also commodity exchanges. The Moscow Commodity Exchange also signed a letter of intent several months ago with the Union of Commercial Banks of Moscow to establish a securities market. Real stock exchange development, however, must await privatization of the economy.

165. Alexander Belozertsev, $A$ Year of Exchanges, 246 Futures and Options World 64 (Nov 1991); Steven Greenhouse, Soviet Commodity Markets Thrive, NY Times C1 col 3 (Oct 21, 1991). Exchanges seem to be popping up everywhere in the Soviet republics. See generally Georgy Plaskin, Fish Exchange Wriggles off Finance Ministry's Hook, Commersant 4 (Sept 9, 1991); Alexander Loktev \& Olga Mushuryan, Germans Return to Koenigsberg via Kaliningrad, Commersant 4 (Sept 9, 1991); The Ukraine Exchanges' Union, N4 Birzhevie Vedomosti 2 (Oct 1991).

Most of the exchanges in the CIS are operated in the form of a joint stock corporation with specified start-up capital. Usually, the shareholders include large state-owned enterprises, state distribution agencies, private cooperatives, small business enterprises, and individuals. The Moscow Commodity Exchange, for example, is registered with the Moscow City Council as a limited shareholder corporation. Its founders include the Executive Committee of the City of Moscow for the Administration of Raw Materials and Equipment Supplies and the USSR Union of Construction Industry Cooperatives. The initial capital contribution of some 12 million rubles for the exchange was to be raised by a $30 \%$ contribution from the founding members and the remainder by sales of limited equity participations. See Siberian Commodity E' Stock Exchange (1991) (description of the structure and operations of a commodity exchange operating in Siberia). In April 1991, the Russian Cabinet set a minimum capital requirement of 10 million rubles for the creation of commodity exchanges. Mikhail Grigoryev, New Russian Exchange Regulations Set, Commersant 9 (April 1, 1991).

The rules and regulations governing the operations of the exchanges are adopted by exchange members. The members may also select the principal exchange manager, who hires the professional staff. As in the United States, there seems to be some tension between the roles of the professional staff and the exchange members. The latter often do not favor any participation by the staff in actual trading operations.

Moscow Commodity Exchange rules include restrictions on access to the trading floor. Only registered traders may participate. Brokers are also required to receive training before trading, and brokers may be penalized for breaking trading customs. Prices are reached by negotiations on the floor, which is arranged into trading pits. In practice, the operations of some of the exchanges are quite colorful. See David Brooks, In U.S.S.R., Possession is Better Than the Law, Wall Si J A 16 col 3 (May 
Initially, the exchanges did not trade much in grains and oil, ${ }^{166}$ but trading in both is now taking place on the exchanges, ${ }^{167}$ which they also offer a wide variety of other goods. In the summer of 1991, for example, the exchanges in Moscow listed over two thousand items, including automobiles, paper, timber, wood products, metals, automated office equipment, construction materials, and consumer goods such as household appliances, furniture, cigarettes, and clothing. ${ }^{168}$ The exchanges have been characterized as "hubs of commerce, acquiring scarce goods, putting market prices on them and selling them." 169 The total turnover in trading on these exchanges is estimated to exceed several billion rubles each month. This trading volume is, however, only a tiny portion of the economy of the former Union. ${ }^{170}$

The scope and size of the exchanges are limited by the fact that they are operating chiefly on an economically inefficient barter basis. ${ }^{171}$ For example,

16, 1991) (description of the Alisa Commodities Exchange which is "staffed by attractive women, some almost six feet tall, of which four feet is legs and six inches is miniskir(").

Executed transactions must be confirmed with the exchange, and the buying broker must pay a commission, which is based on a percentage of the contract price. The Russian Commodities and Raw Material Exchange agreed to restrict dividends so that exchange-imposed commission costs can be kept low. Thereafter, the value of shares in that exchange soared. RCE Reorganizes to Deal With its Success, Commersant 4 (April 1, 1991); Georgy Plaskin, RCRME Hopes to Become Western-Style Bourse, Commersant 4 (Sept 9, 1991); The Russian Commodity and Raw Material Exchange is Celebrating one Year Birthday. Delovoi Mir 1 (Oct 22, 1991). See also Greenhouse, NY Times Cl col 3 (cited in this note) (brokers receive commissions over 60 times larger than an average worker and seat prices on one exchange increased by approximately four million rubles in the last year).

166. Peter Gumbel, Soviet Commodity Trading is the Rage, Wall St J Al9 col 1 (April 10, 1991). More recently, the Moscow Commodity Exchange has proposed to sell American grain through its facilities. Kirill Tanayev, MCE May Trade American Grain, Commersant 4 (Sept 9, 1991).

167. Mark Nicholson, Chrystia Freeland \& Gillian Tett, A Long and Hungry Ride to Market, Fin Times $24 \mathrm{col} 1$ (Oct 1, 1991) (Some 500,000 tons of grain were sold on the Moscow commodity exchanges.); John Lloyd, Moscow Oil Traders Count Their Blessings, Fin Times 32 col 4 (Dec 19, 1991) (Russia allows oil producers to sell $30 \%$ of their production through exchanges.).

168. Alexander Belozertsev, Commodities, The New Currency in the Emerging Soviet Free Market, Commodity Risk, Annual Meeting News Bangkok (Oct 17, 1991). On one exchange, "deals range from wall paneling to condoms to automobiles." Francis X. Clines, A Club for the Oppressed and Insecure: Millionaires, NY Times 2 col 1 (April 27, 1991). The Moscow Commodity Exchange listed over 1,000 items last spring, including trucks, a gun, and a "mini-beer factory." Soviet Futures, The Economist 80 (May 11, 1991). The number of items listed has since increased. See also Sesit, Leningrad Capitalists Await Opening Bell, Wall St J Cl col 4 (May 28, 1991) (Moscow and St. Petersburg exchanges trade building materials such as cement); William B. Crawford, Jr., A Soviet Exchange Student, Chicago Trib S1 col 3 (May 25, 1991) (Soviet exchanges dealing in secondhand goods including heavy equipment, computers, telephones and tools); Alexander Belozertsev, $A$ Year of Exchanges, Futures and Options World 64, 65 (Nov 1991) (two large exchange transactions involved 100 buses and one million Japanese umbrellas). A commodity exchange for loans has also been established. One report states that in February of 1992 rates for a ruble loan were about $45 \%$. Stolyarov, Exchange News, SovData Dialine - BizEkon News (LEXIS) (Feb 21, 1992). A new Russian law prohibits exhange transactions in real estate, intellectual and industrial properties, and art objects. Stoliarov, Stock Exchanges, Prices, Auctions, SovData Dialine - BizEkon News (LEXIS) (February 29, 1992).

169. John Lloyd, The Soriet Union, Growth and Decay While the West Debates, Fin Times 11 col 6 (Oct 14, 1991).

170. Russia's Entrepreneurs: The Wild East, The Economist 40 (Jan 4, 1992); Steven Greenhouse, Soviet Commodity Markets Thrive, NY Times $\mathrm{Cl}$ col 3 (Oct 21, 1991).

171. Turn Off the Presses, The Economist 16 (Oct 5, 1991). Bartering is beginning to play a major role in the Soviet economy. The Moscow Commodity Exchange, for example, is really an auction or clearing house for goods, more akin to the pre-revolutionary trade fairs in Russia. Brian Killen, Soviet 
in a barter economy, a manufacturer of fans needing steel in its operations cannot simply offer a steel producer money for the steel. Instead, he must offer something the steel producer desires, which may not include fans. In one such case, a fan manufacturer obtained smoked fish for fans and exchanged the fish for steel. ${ }^{172}$ This process results in the wasted effort of trying to match interests for barter. It is also a very poor method of price discovery or valuation of products. In contrast, a hard currency will quickly and efficiently allow the valuing of fans, smoked fish, steel, or other commodities. Barter only suggests that there is some uncertain value relationship in what may be a one-time only deal. ${ }^{173}$

The exchanges are reduced to bartering because the ruble is not functioning as an effective exchange medium. ${ }^{174}$ Until that situation is remedied, there can be no effective exchange system in the republics for agricultural products. ${ }^{175}$ The solution to that problem is certainly beyond the

Commodity Exchange Blessed by Priest at COMECON Building, Reuter Library Report, Nexis (Oct 16, 1990); Felicity Barringer, Wide Bartering Keeps Leningrad Going, NY Times A1 col 3 (Sept 4, 1991).

Interestingly, barter operations are also achieving some popularity in the United States. Jordan E. Cohn \& Steve Kaufman, When Money is no Object, Nation's Business 24 (July 1991).

172. Free Fall: While its Economists Debate, The Soviet Union Faces A Catastrophic Slump, The Economist 73 (Sept 28, 1991). See also John Kohan, Strategy for Survival, Time 36 (Dec 9, 1991) (discussion of barter activities by a Soviet truck factory). See generally Privatisation in the Soviet Union. Fanning the Spark of Capitalism, The Economist 82 (May 18, 1991); Craig R. Whitney, Barriers and Frustrations Hamper Succeeding in Business in Moscow, NY Times Al col 3 (Sept 21, 1991) (entrepreneurs reduced to barter to acquire needed equipment).

173. See generally Peter Gumbel, Soviet Commodity Trading is the Rage, Wall St J A 19 col 1 (April 10, 1991); Elisabeth Rubinfien, Americans Help Design Soviet Grain Exchange, Wall St J Al4 col 3 (Dec 14, 1990); Felicity Barringer, Soviet Barter: The Haves and Have-Nots, NY Times Al col 2 (Sept 19, 1991).

174. The loss of confidence in the ruble has led "consumers to invest in tangible assets, from gold and appliances to pure bred dogs and snake venom, to protect their savings." Bill Keller, Soviets to Open Exchanges for Free Trading in Rubles, NY Times Dl col 1 (Aug 8, 1990). The ruble's unreliability helped give rise to the new Moscow Commodity Exchange, that is, it was thought that barter on the exchange could substitute for the ruble. Quentin Peel, Moscow Council Backs Plan to Re-create Commodity Exchange, Fin Times 1 (June 6, 1990).

Barter was a familiar principle to the former Soviet economy during times of upheaval. Ball, The Nepmen at 10-11 (cited in note 40); Malle, Economic Organization (cited in note 42).

175. Steven Greenhouse, Estimate on Gold Worsens Outlook for Soviet Union, NY Times A1 col 2 (Sept 30,1991 ) (discussion of inflationary pressures created in the Soviet Union by the wholesale printing of money; farms may be underreporting production in order to sell produce on the black market). See also Turn Off the Presses, The Economist at 16 (cited in note 171) (same); Peter Norman, $A$ Poor Guest at the Party, Fin Times $18 \mathrm{col} 3$ (Oct 8, 1991) (U.S. officials shocked at the inflationary printing of money in the Soviet Union); Jack Kelley, Soviet Food Rotting in Government Warehouses, USA Today $4 \mathrm{~A}$ col 6 (Dec 19, 1991) (food being withheld in anticipation of higher prices). See generally Rosalind Krasny, Soviets Use Farm Commodities for Bartering, Agweek 13 (March 25, 1991); Celestine Bohlen, As the Ruble Plummets, Hard Currency is King, NY Times Al col 1 (Dec 4, 1991).

The world learned as long ago as the French Revolution that farmers will refuse to sell their grain for paper money that has been devalued by government printing presses. Schama, Citizens at 708 (cited in note 139). 
scope of this article, ${ }^{176}$ but its resolution will be required for an effective exchange system. ${ }^{177}$

\section{VI \\ Benefits of CoMmodity Exchanges}

The agricultural sector has proved to be the former Soviet Union's Achilles heel, ${ }^{178}$ " 'a most critical problem for the Soviet system and its leaders." "179 The Soviets learned as long ago as 1925 that their grain problems are twofold: it is "not enough to increase production"; it is

176. The Soviet government announced in 1990 that it planned to open money exchanges in an effort to transform the ruble into a convertible currency. Bill Keller, Soviets to Open Exchanges for Free Trading in Rubles, NY Times at Dl col 1 (Aug 8, 1990). More recently, the republics decided to abolish the Soviet central bank, Gosbank, in favor of one managed by representatives of the republics. Business This Week, The Economist $77 \mathrm{col} 4$ (Sept 21, 1991). The splintering of the republics, however, has given rise to efforts by the republics to print their own currency and to make the currency convertible. John Lloyd, Yeltsin's Bitter Pill, Fin Times 20 col 3 (Oct 29, 1991); Leyla Boulton, Yeltsin Takes First Market Economy Steps, Fin Times 3 col 1 (Nov 18, 1991); The Time of Money, Komsomolskaya Pravda 2 (Nov 22, 1991); We Will Print Money Ourselves, Vechernaya Moskva 1 (Nov 22, 1991).

Efforts are, in any event, underway to introduce technology into the republics' banking system. Perestroika Meets the Payments System, The Economist 91 (Oct 5, 1991). In the meantime, a commodity exchange in the United States has proposed trading futures contracts on rubles. Lisa Vaughn, Commodities \& Futures: Chicago Board Looks for a Fertile Future, The Independent 19 (July 29, 1991). Exchange trading in currency is also taking place in the CIS. Shaky Balance on the Currency Exchange, Izvestia 8 (Nov 26, 1991). Anthony Robinson, How to Sell Raincoats to Russians, Fin Times 6 col 1 (Jan $3,1992)$.

177. One author has stated that

there can be no market economy without money. The ruble did not fulfill the traditional functions of money even when the Soviet economy was intact: It served neither as a medium of exchange nor as a store of value. Now that the system has broken down, the economy runs on inertia, barter and pilfering.

George Soros, U.S.S.R.: See the Future Make it Work, Wall St J Al0 col 4 (Sept 13, 1991). This author suggests that an internationally sponsored and managed central bank is needed at a cost of some $\$ 40-60$ billion. See also George Melloan, Russian Capitalism, Its Care and Feeding, Wall St J All col 3 (Sept 9, 1991) ("The best way for the West to help the former Soviet Republics is to offer them trade and encourage them to establish convertible currencies"); Peter Norman, Bank of England Training E Europe Central Bankers, Fin Times 1 col 3 (Sept 26, 1991) (Bank of England is training central bankers from the Soviet Union and former East block countries in currency and other aspects of banking in a market economy); Brian Killen, Soviet Commodity Exchange Blessed by Priest At COMECON Building, Reuter Library Report, Nexis (Oct 16, 1990). Some headway is being made in stabilizing the ruble. Laurie Hays, Currency Stuggle, Against Odds, Russia Makes Some Progress in Stabilizing the Ruble, Wall St J Al col 6 (March 2, 1992). The decontrol of prices is also being used to stablize the economy. Yegor Gaidar, Russia Needs Three Kinds of Economic Aid - And Quickly, Fin Times 11 col 1 (Jan 22, 1992).

Another point of view is that currency reform will take care of itself if a market economy can be made to function. Making it in the Soviet Union, Institutional Investor 29-30 (May 1991). See also Charles Bean, et al, Soviet Republics Should Supplement Rouble With Hard Foreign Currency, Fin Times 21 col 1 (Oct 1, 1991) (London economists suggest supplementing the ruble with a low inflation currency such as the dollar).

178. The difficulty of bringing agricultural goods into a market economy is not a problem that is either new or limited to the republics. As recognized by one author discussing the French Revolution, agricultural goods are "the most sluggish of all commodities to reach a market economy." Schama, Citizens at 190 (cited in note 139).

179. Hill, The Soviet Union, Politics, Economics and Society from Lenin to Gorbachev at 173 (cited in note 87) (citation omitted). 
necessary also "to increase the volume of grain actually put on the market." 180 The development of modern commodity exchanges is important to solving these dual problems. ${ }^{181}$ Exchanges encourage greater production and infuse grain into the market centers for consumption.

The exchange establishes a means whereby growers can dispose of grain at market prices. This encourages farmers to produce more because they can use the excess to purchase (now barter) additional goods and luxuries. There is little incentive to produce greater amounts if the State is going to purchase the surplus at non-market prices or with an inflated ruble. ${ }^{182} \mathrm{~A}$ commodity exchange distribution system will also bring more grain to the market. One way the supply is increased is through the efforts of brokers, who receive a fee or commission to ferret out grain and bring it to the market. This practice reduces the waste and spoilage that is endemic to the republics' present distribution system. These incentives will also encourage the development of an infrastructure that will bring the republics' agricultural sector more in line with modern systems where grain merchants play the role of middlemen.

Under a commodity exchange distribution system, producers and grain merchants will see to the development of elevators and silos for grain storage, stemming some of the large losses currently incurred through improper storage. Later, in more advanced stages of development, the exchanges will allow hedging and efficient price discovery such as that found in the United States. ${ }^{183}$ In times of actual or anticipated shortage of a particular commodity, producers will be notified of expected needs and anticipated shortages by futures price reports from the exchanges. Those price reports will reflect shortage concerns through increased price levels. Producers will then be notified of expected future demand and anticipated shortages and will be able to plan accordingly by increasing production of that commodity. In the meantime, increased prices will draw scarce commodities from external sources to alleviate the shortage. The converse will be true where there is an overproduction of a particular commodity.

180. Edward Carr \& R.W. Davies, I Foundations of a Planned Economy 1926-1929, at 3 (Macmillan, 1969).

181. As one Russian commodity exchange official stated: "[ $t$ ]he commodities market is the first step toward developing a capital market." Mark Berniker, Moscow Plans to Launch Commodities Market Soon, J Comm lA (June 12, 1990).

182. In 1990, the Soviet government allowed about $20 \%$ of production to be marketed privately by farmers as a means to stimulate agriculture. Elisabeth Rubenfien, Americans Help Design Soviet Grain Exchange, Wall St J A 14 col 3 (Dec 14, 1990). However, this modest step has not proved effective. Even now, grain is being withheld from distribution and is being left to rot in the fields because of a lack of market incentives. Francis X. Clines, Grim as Ever, the Thought of Winter Stalks Russia's Spirit, NY Times E3 col 1 (Sept 22, 1991); Steve Lohr, Aid Request Would Tax Soviet Distribution System, NY Times A4 col 3 (Sept 20, 1991); Europe Urges Rise in Soviet Aid, NY Times A4 col 1 (Oct 8, 1991). See also Francis X. Clines, 10 Soviet Republics Agree to Coordinate Food Supply, NY Times A5 col 1 (Sept 17, 1991) (food production in the Soviet Union has been dropping at an annual rate of 10 to $12 \%$ ); Keith Bradsher, US Planning \$1.5 Billion in Food Aid to Soviet Peoples Through Moscow, NY Times A6 col 4 (Nov 21, 1991) (U.S. Secretary of Agriculture advises Congress that food distribution is a serious problem in the Soviet Union and that the 1990 grain harvest will be much reduced).

183. See generally Western Involvement in Moscow Commodity Exchange Urged, Milling and Baking News (June 1991) (price discovery needed in Soviet Union). 
Of course, the exchanges will not themselves make a harvest successful or establish prices. They will, however, assure that commodities are produced and sold in the most efficient manner. They will also allow individual entrepreneurs to make pricing and related commercial decisions on a more rational basis.

VII

\section{Steps Needed to Create A Commodity Exchange Distribution System}

A number of steps are needed for the development of a modern exchange distribution system in the CIS. These include: (a) privatization of farmland and development of middlemen to market grain; (b) implementation of modern exchange trading concepts; (c) development of appropriate regulations for traders; and (d) a re-entry of the CIS into the international grain markets. Each of these steps is discussed below.

\section{A. Privatizing the Agricultural Sector}

A fundamental obstacle to the development of a market economy in the CIS is the lack of a concept of private property, which had been rejected by the former Soviet Union. A report by the European Bank for Reconstruction and Development thus found that some twenty-eight percent of all grain and as much as fifty percent of all potatoes produced in the former Soviet Union were simply "lost" before reaching consumers. These losses were due to inefficiency and "the absence of private property, which means people regard state property and goods as "belonging to no one." "184 Privatization of state enterprises would help cure these problems and increase production and delivery in all sectors of the economy, not just agriculture. This will not, however, happen instantly, by accident, or without pain. ${ }^{185}$ Nevertheless, the concept of private ownership must be accepted and implemented before a market economy can function. ${ }^{186}$

Privatization must also be carried out in a manner that will stimulate distribution as well as production. Such stimulation can be provided even in

184. Half Soviet Potatoes Never Reach Consumer, Fin Times 7 col 1 (Oct 16, 1991).

185. Early in American history, vast amounts of land were distributed by the government at very low prices. The free market, including speculators, was allowed to play a large role in that process. We should not forget, however, that distribution took place at the expense of Native Americans. Paul Johnson, The Birth of the Modern World Society 1815-1830, at 211-31 (Harper Collins, 1991).

186. The whole concept of ownership must be established in the CIS. See David Brooks, In U.S.S.R., Possession is Better Than the Law, Wall St J Al6 col 3 (May 16, 1991) (description of the concerns of the owner of the Alisa Commodities Exchange that the lack of ownership rights in the Soviet Union threatens entrepreneurs); Celestine Bohlen, Red Square Pageantry Gives Way to the Angry, NY Times A6 col 1 (Nov 8, 1991) (demonstrations against private ownership are held in Red Square). See generally Voucher Power, The Economist 18 (Sept 21, 1991) (giving companies away is better than keeping them in state hands); Francis X. Clines, Next: The Gold Rush on Apartments, NY Times A7 col 3 (Oct 15, 1991) (discussion of apartment auctions and black market traffic in Moscow apartments); Michael Dobbs, Crawling Toward Revolution, Washington Post Al col 3 (Dec 22, 1991) (discussing lack of understanding by the Soviet public of what a market economy entails); There Will be More Freedom, Kuranty 1 (Nov 22, 1991). 
the context of present barter arrangements; for example, farm land could be sold for production credits. That is, when arable land is distributed to private owners, it could be purchased with bushels of wheat or other grain actually delivered to a delivery point external to the farm. This does not mean delivery to the government; rather, delivery would be into the private market economy in any form so long as it was external to the farm. ${ }^{187}$

The sale price of the land would be based on current production for, say, the next ten years or, perhaps, by an amount set by competitive auction of the land. ${ }^{188}$ Bonuses might also be in order: If, for example, present production increases by more than ten percent, that ten percent could count double in reducing the grain mortgage. The farmer should also be allowed to keep whatever currency might be received from the introduction of the grain into the production system. ${ }^{189}$ These incentives would provide a methodology for distributing the land, and they would provide incentives for increasing production and external shipments to an exchange distribution system. ${ }^{190}$

Middleman assistance and incentives are also needed. For example, silos and elevators will be necessary for the local and regional assemblage of grain in preparation for distribution to urban centers. Such storage facilities are needed to reduce the thirty percent or more of the republics' crop that is

187. Current economic reform plans do not appear to envision any such incentives. Rather, it appears that collective farm members would simply be allowed to leave the collective, and possibly keep a portion of the land, if they keep it under cultivation. Padma Desai, Soviet Economic Reform: A Tale of Two Plans, 3 Harriman Inst Forum No 12 at 1 (Dec 1990); Working Group Formed by M. S. Gorbachew and B. N. Yeltsin, Transition to the Market pt 1 at 126-30 (Aug 1990); Stanislav S. Shatalin et al., 500 Days: Transition to the Market 161-71 (St Martin's, 1991). See also Yeltsin Goes for It, The Economist 16-17 (Nov 2, 1991); Russia Stepping Out, The Economist 44 (Nov 2, 1991) (Russia plans to give away bankrupt state farms and to allow the purchase and sale of land.); Francis X. Clines, Yeltsin Signs Law on Land Reform as Part of Wider Economic Plan, NY Times Y4 col 1 (Dec 29, 1991) (same); David Remnick, Yelisin Sets Reforms for State Land, Washington Post Al col 5 (Dec 29, 1991) (same). See also Gillian Tett, Lithuania Takes Slow, Painful Route to a Market Economy, Fin Times $4 \mathrm{col} 1$ (Nov 19, 1991) (Lithuania is utilizing a voucher system distributed on the basis of work history and age. Recipients may then use their vouchers to bid on property). The Russian government has adopted a law to authorize the selling of land to private citizens, and a government corporation is being formed to organize the use of the land in Russia. Lofenfeld, Investors are Finding Soil Beneath Their Feet, SovData Dialine - BizEkon News (LEXIS) (March 9, 1992); Silvanovich, The Earthly Worries of Alexander Rutskoi, SovData Dialine - BizEkon News, (LEXIS) (March 13, 1992). In the meantime, the land is simply being given away in Russia, Russian Farming, The Least Likely Agricultural Miracle, The Economist 71 (April 11, 1992), while ownership remains uncertain, Ivan Yelistratov, Serghei Chugayev, Valery Konovalov, By Congress's Will Land in Russia has no Master - As Before; the Farmer Can be Ordered About so Long as he is no Proprietor, Soviet Press Digest, (LEXIS) (April 17, 1992) (Russian Congress rejects constitutional amendment allowing sale and purchase of land).

188. Obviously, such auctions raise complex fairness issues. If the auctions are limited to present members of the farm units, low-ball bidding may result. Therefore, a bidding floor should be set based on past or estimated production. If outside competitive bidding is thought necessary, verification of the bidders' financial wherewithal will be needed as well as some deposit to assure that fraudulent or unrealistic bids are not submitted.

189. Cheaters in this process could be subject to civil and criminal sanctions or to the loss of their land. For example, anyone submitting false documentation of their market deliveries could be subject to such sanctions.

190. The government has used grain auctions in Moscow to induce grain to that market center. The stimulus for participation were competition for the rights to purchase automobiles at low official prices. Alexander Belozertsev, Grain Auctions in Moscow, Izvestia 1 col 3 (Feb 16, 1991). 
wasted each year. ${ }^{191}$ Assistance in this area is being provided in the form of proposals to create complete distribution networks. ${ }^{192}$

One way to stimulate development of storage and merchandising facilities like those used by grain merchant firms in the United States and other Western countries is to loan or sell property and equipment to entrepreneurs. ${ }^{193}$ At early stages, these merchants should also be given loans and grants for acquiring farm equipment, seeds, fertilizer, and other commodities for barter or sale to the farmers. ${ }^{194}$ Repayment or payment, at least partially, would be in the form of credits for the bushels of grain moved from the farmer to the market and into the hands of processors or consumers of the commodity. The United States and other Western countries could provide aid to fund these programs. ${ }^{195}$ Such assistance would be much more effective in assuring the implementation of a market economy than money spent to relieve short-term shortfalls. The latter offers nothing more than the faintest of hopes for market reform, while the former will assure its implementation. ${ }^{196}$

The receipt of a middleman's markup or brokerage fee may be difficult for the Soviets to encourage or even swallow, much less subsidize. The concept of a broker's or middleman's profit is still viewed with some suspicion. It smacks of speculation, a matter of particular concern under Marxist theory,

191. The amount of waste may actually be approaching $40 \%$. Steven Greenhouse, Soviet Depression Hits the Cows and Chickens, NY Times A8 col 1 (Nov 1, 1991).

192. Alan Murray, Soviet Hunger for Help is Feast for Small U.S. Concerns, Wall St J B2 col 3 (Oct 23 , 1991). See also Myron R. Laserson \& C. Phillip Baumel, Industry Note, Grain Transportation and Distribution Research Needs in Grain Importing Countries: The Case of the Soviet Union, 7 Agri Bus 285 (1991) (description of the inadequacies of the Soviet grain transportation system). The Russian government is now transferring ownership of the existing, and inadequate, elevators and other grain storage facilities to local governments. Hopefully, they will privatize them. Resolution Defines Ownership of State Assets at Different Levels of Government, Soviet Bus Law Rpt (LEXIS) (Feb 7, 1992).

193. The republics' harvesting machinery is particularly inefficient. Russia's Entrepreneurs: The Wild East, The Economist 40, 41 (Jan 4, 1992). The head of one large grain firm in the United States has also been advising the republics for several years that the development of silos could save the $30 \%$ of their grain harvest that now rots each year. American Business Sees Red. For Some U.S. Companies in the Soviet Union, it's Time to Lie Low, US News \& World Rpt 49, 50 (July 8, 1991). See generally Francis X. Clines, Grim as Ever, the Thought of Winter Stalks Russia's Spirit, NY Times E3 col 1 (Sept 22, 1991). Farmers from the former Soviet Union are being trained in modern farming techniques. Looking West, In Canada, Ukrainians Discover the "Lost" Art of Modern Farming, Wall St J Al col 1 (Jan 24, 1992). Farmers in the new Commonwealth are also husbanding their equipment in expectation of greater shortages and the loss of brigade workers to assist in the harvest. Ishkova, Harvest Prospects, SovData Dialine - BizEkon News (LEXIS) (March 4, 1992).

194. Russia is itself planning to give some four billion dollars' worth of farm equipment to farmers. Russia, Stepping Out, The Economist 44 (Nov 2, 1991).

195. The grain distribution system in the United States is itself heavily subsidized. Keith Bradsher, The Mixed Blessing of Empty Bins, NY Times Cl col 3 (Nov 6, 1991).

196. Middlemen incentives should also reduce the enormous amount of waste that occurs in the transportation of grain in the republics. See Mark Nicholson, Chrystia Freeland \& Gillian Tett, $A$ Long and Hungry Ride to Market, Fin Times 21 col 1 (Oct 1, 1991) (describing transportation waste in the Soviet Union).

The development of a modern distribution system in the republics will cost many billions of dollars. Alan Murray, Soviet Hunger for Help is Feast for Small U.S. Concerns, Wall St J (Oct 23, 1991). Unfortunately, the United States has slated only several million dollars in technical assistance to aid the Soviet Union in this area of development. Keith Bradsher, U.S. to Announce $\$ 1$ Billion in Food Aid to Soviets, NY Times A4 col 4 (Nov 7, 1991). 
the thought being that speculators gorge off the misery of others. ${ }^{197}$ As Adam Smith recognized some two hundred years ago, however, speculators serve the function of rationing the supply of commodities. ${ }^{198}$ Speculators ferret out supplies and bring them to the place of demand in the most efficient manner so as to maximize their profits. ${ }^{199}$ There they charge what the market will bear. Consumers are then faced with the task of accumulating resources to purchase those goods. The amount of those resources will determine the strength of demand for goods and services.

Speculation has already become widespread in the CIS, as consumers barter and deal in the black market. ${ }^{200}$ Nevertheless, obtaining official and popular recognition that speculators play a valuable role will be difficult, especially when prices increase and shortages grow, because there will be a tendency to blame "hoarders" and speculators for these $\mathrm{ills},{ }^{201}$ a viewpoint

197. Speculation was a "heinous" crime. Peter Gumbel, Soviet Commodity Trading is the Rage, Wall St J A19 col 1 (April 10, 1991). " "What is commerce in other countries is the crime of speculation here,' said Mr. Sterligov, seated in his commodity exchange." Francis X. Clines, A Club for the Oppressed and Insecure: Millionaires, NY Times 2 col 1 (April 27, 1991). The government, however, is acting to remove prohibitions against speculation. Russia Federation Penal Code has Become Shorter and More Lenient, Commersant 24 (Nov 25, 1991) (Russian lawmakers have decided to eliminate penal code provisions dealing with “business and middleman's activities"); Decree of the President of the Russian Federation on Freedom of Trade, Rossiiskaya Gazeta, Feb 1, 1992, reprinted, CDSP (NExIS, International) (March 4, 1992).

198. Adam Smith, 4 An Inquiry Into the Nature and Causes of the Wealth of Nations (5th ed 1789), noted in Note, Prevention of Commodity Futures Manipulation Under the Commodity Exchange Act, 54 Harv L Rev 1373, $1374 \mathrm{n} 6$ (1941). Still, middlemen were blamed for the grain shortages that occurred in England 200 years ago. Johnson, The Birth of the Modern, World Society 1815-1830, at 363 (cited in note 185).

199. The republics' present marketing system is inefficient and unreliable. Nove, The Soviet Economic System at 118 (cited in note 82). Commodity exchange participants have been organizing transportation companies to relieve some of the shortcomings in the transportation and marketing system. Alyabyev, Business People Falling in to Disgrace, SovData Dialine - BizEkon News (LEXIS) (Feb 25,1992 ).

200. The "black," "brown," and "grey" markets in the republics have already established a "shadow" economy of uncertain dimensions. David Lane, Soviet Economy and Society 64-67 (Basil Blackwell, 1985). See also Fred Hiatt \& Margaret Shapiro, Nice Food - If You Can Get lt, Washington Post A1 col 1 (Nov 24, 1991) (discussion of widespread black market transactions in the CIS). In fact, one of the factors motivating the creation of the Moscow Commodity Exchange was the thought that it could serve as an alternative to the black market. Moscow Starts Commodities Exchange, UPI (NEXIS) (June 2, 1990); Moscow Opens Commodity Exchange, Telegraph Agency of the Soviet Union (TASS), (Nexis) (June 2, 1990); The First Soviet Commodities Exchange, BBC, Summary of World Broadcasts, (Nexis) (June 5, 1990).

201. See generally Nove, The Soviet Economic System at 119 (cited in note 82). One Chicago commodity exchange official found on a visit to the Soviet Union in 1991 that there still existed a strong antipathy towards capitalism and profit making. R. C. Longworth, Melamed Goes to Moscow to see Future, but finds Chaos, Chicago Trib 3 col 1 (Nov 9, 1990). See also Serge Schmemann, Once a Rich Farm, Now a Soviet Casualty, NY Times 1 col 2 (Nov 17, 1991) (Soviet farmers resist introduction of market prices because it suggests speculation.).

The Mayor of Moscow has also been given authority to impose price controls. This threatens the viability of commodity exchanges because controls will stop trading and mové transactions back to the black market. Craig R. Whitney, Barriers and Frustrations Hamper Succeeding in Business in Moscow, NY Times Al col 3 (Sept 21, 1991). See also Craig R. Whitney, Communism is Dead: Other Problems are Alive, NY Times A5 col 3 (Sept 17, 1991) (suggestion that there will be public unrest when subsidized prices are replaced by much higher market prices); Neela Banerjee, Unions Give Voice to Struggling Russians Tired of Yeltsin's Economic Promises, Wall St J A19 col 5 (Oct 31, 1991) (unions resist efforts to convert to market economy); Francis X. Clines, Prices Already Soaring in Soviet Shops, NY Times A3 col 4 (Nov 1, 1991) (Soviet consumers grow restive as prices increase and shortages grow); Leyla Boulton, 
that may lead to an unfortunate repetition of the mistakes made during the Soviet Union's communist planning. High prices and hoarding are symptoms of a failed economy. Speculators and middlemen are the persons who obtain goods from "hoarders" by giving them an incentive to part with their goods. More importantly, they provide the incentives for greater production, thereby relieving shortages and reducing prices. ${ }^{202}$

\section{B. Exchange Development}

The continued development of commodity exchanges in the CIS can be carried out even as the privatization process and the implementation of a hard currency are underway. For example, one needed step in the exchange development process will be the creation of forward contracts. ${ }^{203}$ Here, the exchanges can learn from the American experience. Forward contracts assure the farmers that their production will be purchased for cash that can be used for necessary or discretionary purchases. This, in addition to any incentive provided by the land-for-grain purchases, will stimulate the farmers to produce maximum amounts of grain. Maximizing production will stop the current shortages that are being encountered in the republics' economies.

Forward contracts will also assure that producers maximize the use of distribution facilities, ${ }^{204}$ making it unnecessary to bring all of the grain to urban centers at harvest time, which only results in great waste in produce and snarled transportation facilities, as well as requiring a mini-mobilization of the army and students to assist in the harvest. Forward contracts require the grain only when it is needed. Therefore, it can be stored locally or regionally until needed at an urban center or even at a far removed processing plant. In that regard, the use of forward contracts will encourage, indeed mandate, the building of storage facilities for the grain until the forward contracts require its delivery. ${ }^{205}$

Rich and Poor Unite in Distrust of Yeltsin, Fin Times 3 col 4 (Nov 29, 1991) (same); Barry Newman, Locked Larders, Amid Soviet Disarray, Some Farmers Refuse to Ship Food to Cities, Wall St J Al col 1 (Nov 12, 1991) (farmers are hoarding products and consumer shortages grow).

The new-found wealth of traders and its attending conspicuous consumption may not help matters. John Lloyd, The Soviet Union: Growth and Decay While the West Debates, Fin Times 11 col 6 (Oct 14, 1991) (describing Soviet exchange traders as "raucous and sharp, run by men and women who are young and often crudely acquisitive and arrogant in their assertion of new power ...").

202. In the past the Soviet Union was forced to use military personnel and students to harvest crops. Felicity Barringer, Moscow State Changes its Books and Ideology, NY Times A5 col 1 (Sept 25, 1991); Steven Greenhouse, Estimate on Gold Worsens Outlook for Soviet Union, NY Times Al col 2 (Sept 30,1991 ).

203. The Prospectives of Cash Forward and Futures Trade in the Soviet Union, 4 Birzhevie Vedomosti 7 (Oct, 1991). The exchanges will be able only gradually to adopt the modern futures trading principles utilized on exchanges in the United States. In the interim, cash or forward contracts can be used for trading. Gordon Platt, Leningrad Moves Ahead With Exchange Plans, J Comm (Feb 15, 1991). For a discussion of forward contracts, see notes $143-44$ and accompanying text.

204. See generally Western Involvement in Moscow Commodity Exchange Urged, Milling and Baking News (June 1991).

205. The development of a sound infrastructure of silos and grain elevators will also allow storage of grain surpluses for use in periods of reduced production caused by adverse weather or other conditions. 
Several practical problems must also be overcome before an effective exchange distribution system will function in the CIS. For example, the people will need to be educated about the role and use of commodity markets. In this regard, technical assistance is needed to develop expertise on how exchanges function in a market economy and how exchanges conduct their everyday affairs. Such assistance is being supplied by exchanges in the United States. In November 1990, the Chicago Board of Trade and the Chicago Mercantile Exchange signed memoranda of understandings with an agency of the Government of the Soviet Union, the Russian Federation government, and the Moscow City Council. Pursuant to those memoranda, the Chicago exchanges have provided materials and technical assistance to the Moscow Commodity Exchange and to the Ryazan Commodity Exchange. The Chicago exchanges are further planning to create teaching programs for specialists from the Soviet exchanges. ${ }^{206}$

If commodity trading is to be effective, modern communication facilities must also be developed to convey market quotations and execution orders to users of the markets throughout the CIS. ${ }^{207}$ This will require an effort comparable to that of MCI's development of an alternate communications network in the United States, ${ }^{208}$ only the task will be of greater magnitude. ${ }^{209}$ The United States and other countries can provide assistance to the CIS in establishing communications systems. This area is amenable to joint ventures, and the development of communication facilities would also be appropriate for aid grants from other governments.

In addition, the CIS will need advice on developing trading systems that will handle the entry orders and their posting on the floor, as well as computers for processing and matching orders for confirmation and settlement. The CIS exchanges appear to be receiving such advice from the Chicago exchanges and elsewhere. ${ }^{210}$ A Swedish company has also agreed to

206. See generally Barbara Durr, Chicago Signs Moscow Accord, Fin Times (Nov 1, 1990); Confusion Hits CBOT, CME, Over After Hours Use of Aurora, Trading Systems Tech (Nov 5, 1990). The agreement between the Chicago Exchange and the agency of the former Soviet Union is no longer in effect.

207. Communication facilities in the former Soviet Union are notoriously poor. One Chicago commodity exchange official visiting the Moscow exchanges was appalled to find that he could not even telephone his exchange from the Kremlin. Longworth, Chicago Trib at 3 col 1 (cited in note 201). In 1991, the Moscow Commodity Exchange had only three phones for 70 brokers. Peter Gumbel, Soviet Commodity Trading is the Rage, Wall St J A19 col 1 (April 10, 1991). Consequently, the acquisition of communication facilities has been a matter of high priority for CIS exchanges. Francis X. Clines, Moscow Journal: From Black (or Red) Market to White, NY Times 4 col 1 (June 16, 1990). Apparently modern communications are now being introduced on the exchanges. Francis X. Clines, $A$ Club for the Oppressed and Insecure: Millionaires, NY Times 2 col 1 (April 27, 1991) (description of a trader using a portable phone).

208. See generally Larry Kahaner, On the Line: The Men of MCI-Who Took on ATET, Risked Everything, and Won! (Warner Books, 1986) (history of MCI).

209. One commentator has suggested that joint efforts in the republics with American firms would be a productive way to introduce American technology and industry. Such efforts could be backed in part by the government of the United States. George Melloan, Feed the Russians? It Could be Easy, Wall St J A19 col 3 (Sept 16, 1991). Private efforts are already underway. John Keller, $A T \mathcal{E}^{2} T$ Signs Big Contract to Supply Former Soviet Republic With Phone Gear, Wall St J A2 col 3 (March 18, 1992); Telecommunications in Eastern Europe, Finding Their Voice, The Economist 74 (Feb 8, 1992).

210. See note 206 and accompanying text. 
establish an electronic trading system for order entry and execution on the commodity exchange in what is now St. Petersburg. ${ }^{211}$

Another concern is the high rate of default on the fledgling exchanges in the CIS, such as where promised goods are not delivered or they are something other than what was promised. ${ }^{212}$ To deal with such problems, the exchanges must develop a clearing-house system such as that found on other exchanges around the world. Once more, the CIS can benefit from the experience of the Western exchanges. Clearing houses provide facilities for matching trades, settling positions, and reducing counterpart risks by performance guarantees. ${ }^{213}$ This means that if one party fails to perform on the contract, the clearing house will assume the responsibility for performance in damages or by delivery itself. Only the creditworthiness of the clearing house needs to be considered, not the individual credit of the opposite party. ${ }^{214}$ Performance may further be secured by margin requirements. ${ }^{215}$

211. Platt, J Comm (cited in note 203); Hal Lux, Electronic Trading System Underway for Leningrad Mart, Investment Dealer's Digest (Dec 17, 1990); Swedish Socialism is Aiding Russian Capitalism, Rossiyskaia Gazeta 1 (Oct 8, 1991).

Russia seems to have already created its own fledgling equivalent to the Wall Street Journal. This publication, "Commersant," was started with the assistance of the owner of a large commodity brokerage firm in the United States. Kevin Maney, Tabloid Aims for Media Big Leagues, USA Today B 1 col 3 (Oct 21, 1991).

212 . For example, brokers sometimes " 'sell air,' selling goods before the owners have committed themselves to a sale," or they may sell "five trucks of butter, which turn out to be five vans." Steven Greenhouse, Soviet Commodity Markets Thrive, NY Times C1 col 3 (Oct 21, 1991). See generally Peter Gumbel, Soviet Commodity Trading is the Rage, Wall St J A19 col 1 (April 10, 1991).

213. One court has noted the following:

'Clearing' is a term of art with a special meaning in the commodity futures market. . . Every commodity futures exchange has an affiliated 'Clearing House' which stands behind every trade, thus ensuring performance of the contract and facilitating liquidity in the market place .... Every trade that is executed must be accepted for clearance by a member of the Clearing House. When a trade is cleared, the Clearing House substitutes itself for the immediate parties to the contract. ... This way, every trade is cleared, so the party on the other side of the trade . . . is assured of performance of the contract. Thus, "the honoring of contractual obligations is not dependent upon the actions or solvency of any single trader."

Peltz v SHB Commodities, Inc., 2 Comm Fut L Rep (CCH) I 24,810, at I $36,836-37$ (SD NY 1990) (citations omitted). See also Roger D. Rutz, Clearance, Payment, and Settlement Systems in the Futures, Options, and Stock Markets (Board of Trade Cleaning Corporation, 1989) (description of clearing systems in the United States).

214. The credit of clearing houses in the United States is backed by the credit of all their members and by clearing funds that are accumulated by transaction fees. See generally Hieronymus, Economics of Futures Trading at 43-45 (cited in note 115); Chicago Board of Trade, Commodity Trading Manual 28-31 (1982).

215. In the futures industry, margin is used as a good faith payment of money to assure performance on contracts. There are two forms of margin-initial and variation. Initial margin is a small percentage of the total contract price that must be paid on initiating the contract. Variation margin must be paid daily to reflect variations in the value of the underlying commodity. Margin for futures contracts is distinguished from margin for securities, with the latter a limitation on credit and not a means to assure performance as is the case for futures contracts. Jerry W. Markham, Federal Regulation of Margin in the Commodity Futures Industry, 64 Temple L Rev 59 (1991).

The Moscow Commodity Exchange has developed a clearing house that requires traders to confirm their orders with it, and procedures for handling errors have been established. In addition, customers are required to post margin with their broker to assure performance on their contracts. Currently, this is an amount equal to about $3 \%$ of the contract value. An effort is also underway to 
Equally important to the exchanges will be the development of dispute resolution systems to deal with traders that default, quality and grade disputes, and trade report, execution, and other errors. There are no commercial courts in the CIS comparable to those in Western countries. ${ }^{216}$ Therefore, some alternate dispute resolution systems, such as arbitration, are needed. Arbitration may be the most desirable in that it is a popular mechanism for dispute resolution on exchanges around the world. The CIS could, for example, adopt arbitration procedures such as those used on commodity exchanges in the United States. ${ }^{217}$

The exchanges must develop some standardized contract terms for agricultural commodities. ${ }^{218}$ Standardization need not go at least initially, as far as futures contracts in the United States. However, essential terms such as grade, quality, and delivery requirements should be made regular. ${ }^{219}$ Another critical requirement for the effective operations of the exchanges is the approval of warehouses for delivery and storage of grain. ${ }^{220}$ This will assure the integrity of the grain being delivered, as well as its proper storage until use. The exchanges may also want to develop alternate delivery points on exchange-traded contracts for the convenience of traders. Alternate delivery points would have the peripheral benefit of preventing manipulation of grain prices, as where a single trader gains control of all supplies that can be brought to a single delivery point. ${ }^{221}$ This was a perennial problem in the early days of exchange trading in the United States. ${ }^{222}$

With these steps accomplished or underway, the next stage of exchange development in the CIS will involve the adoption of futures contracts, which will offer multiple benefits to the economy. Here again, the CIS could learn

create a bank that will provide exchange credits and act as a clearing house. The Creation of Russia Exchange Bank, 4 Birzhevie Vedomosti 9 (Oct 1991).

216. See generally Louis Uchitelle, The Art of a Russian Deal: Ad-libbing Contract Law, NY Times A 1 col 3 (Jan 17, 1992); William E. Butler, The Soviet Legal System Legislation and Documentation (Oceana Publications, 1978); Stephen Breyer, Russian Judges Want Real Justice, NY Times A15 col 2 (Oct 30 , 1991).

217. See Phillip Johnson \& Thomas Hazen, 1 Commodities Regulation $\$ 1.28$ at $105-06$ (Little, Brown, 2d ed 1989) (discussion of arbitration on U.S. exchanges).

The exchanges have formed a Congress of Exchanges to develop exchange clearing systems, arbitration, and other uniform measures needed for the development of the exchanges. In addition, the Inter-Regional Exchange Union has been formed to promote the development of exchanges, and the Brokers' Guild has been organized to promote and protect the interests of brokers that are trading on the exchanges.

218. See generally 2 Grain Exporters at 6 (cited in note 44) (discussion of the importance of standardized grades for grain).

219. The establishment and monitoring of these and other contract terms are made conditions of exchange licensing requirements in the United States. 7 USC $\S \S 7,7 a(1991)$. Grain standards are

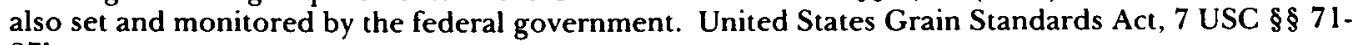
87h.

220. Warehouses are subject to federal and exchange regulation in the United States under the Commodity Exchange Act, 7 USC $\S 7 \mathrm{a}$, and the United States Warehouse Act. 7 USC $\S \S 241-72$.

221. Delivery points are subject to the approval of the Commodity Futures Trading Commission in the United States in order to assure that the futures contracts are not susceptible to price manipulations. 7 USC $\$ 7 \mathrm{a}(10)$.

222. See generally Jerry W. Markham, Manipulation of Commodity Futures Prices-The Unprosecutable Crime, 8 Yale J Reg 281 (1991). 
from the American experience. Since futures contracts are standardized, they can be used to hedge commercial risks. This will allow producers to stabilize the prices paid for goods used in production. Price stability is a matter of particular concern during inflationary periods such as the one the CIS is now experiencing. Futures contracts also standardize commodity qualities and quantities, allowing for easier financing and greater confidence for those dealing in the commodity. The use of a clearing house, as noted, also removes counter-party risk, a particularly troubling problem in a developing economy. The elimination of that risk will greatly facilitate commodity transactions and distribution. ${ }^{223}$

\section{Regulatory Concerns}

The development of commodity exchanges in the CIS will not be without costs. In addition to the incentive and implementation costs already mentioned, there will be serious abuses, especially by those seeking advantage in the formative stages of the exchanges. ${ }^{224}$ The United States paid a severe price for the manipulations that were regularly carried out during the early days of exchange trading. Those manipulations caused hardships for farmers and consumers, and they resulted in economic inefficiency when supplies were diverted to market centers by artificial prices that did not reflect actual demand for the commodity. ${ }^{225}$ The exchanges are always susceptible to fraudulent trading practices, as was dramatically evidenced by the recent FBI undercover operations in Chicago, which disclosed widespread cheating of customers. ${ }^{226}$

The CIS would, therefore, be well advised to study the American experience. The public and market participants will not have confidence in markets that are subject to manipulation and fraud, and it is the government's duty to safeguard against such abuses. Such safeguarding must include

223. The lack of traders in the Soviet Union causes wide price disparities. For example, in July 1991, oil prices at the Tyumen Commodity and Stock Exchange fluctuated from 280 to 450 rubles per ton. There were only two real buyers participating in the trading session. Nevertheless, the exchanges are now providing some pricing information to the rest of the world, and Reuters and Petroleum Argus are reporting trading on the Siberian and Moscow exchanges. See John Lloyd, Moscow Oil Traders Count Their Blessings, Fin Times 32 col 4 (Dec 19, 1991) (Russia allows oil producers to sell $30 \%$ of their production through exchanges and a Moscow exchange reports large transactions).

224. Some abuses are already occurring. Stephen Greenhouse, Soziet Commodity Markets Thrive, NY Times Cl col 3 (Oct 21, 1991). See also Crime Record, Sem' S Plyusom 5 (Nov 22, 1991) (Central Bureau for Economic Crimes announces that economic crime reports have increased by $7.4 \%$ from the same period in 1990).

225. Jerry W. Markham, The History of Commodity Futures Trading and Its Regulation ch 1, 3-21 (Praeger, 1987) (general history of abuses in the futures markets in the United States); 5 FTC, Rept on the Grain Trade 323 (1923) (discussion of early manipulations); Michael Reynolds, Enforcing Anti-Trust Law in Central Europe, Fin Times 14 col 5 (Sept 26, 1991) ("Experience in the UK has shown how important it is to ensure that newly-privatized undertakings are subject to supervision and regulation"); Business in Eastern Europe, The Economist 20 (Sept 21, 1991) (Eastern European exchanges expect abuses. "It will be [like the] wild west"; it happened in America and it will happen there.).

226. See generally David Greising \& Laurie Morse, Brokers, Bagmen, and Moles: Fraud and Corruption in the Chicago Futures Markets (John Wiley \& Sons, 1991). 
prosecution of those engaging in such activities and regulatory safeguards against abuses. A study of the securities and commodity regulatory schemes in the United States would be useful in that regard. ${ }^{227}$ The greatest dangers to the exchanges, however, is that the government will not limit itself to such a narrow role. The temptation to regulate rising prices by restricting exchanges activities is almost as irresistible as it is futile. Exchanges will operate successfully only if market forces, rather than government bureaucrats, are free to set prices. The exchanges should be allowed to regulate themselves to the maximum extent possible, with government regulation strictly limited to preventing fraud, manipulation, and other abuses. ${ }^{228}$

\section{The International Markets}

The exchanges in the CIS are now acting on many of these issues, but efforts must also be made to bring them back into the international grain markets. ${ }^{229}$ The commodity exchanges are playing an increasing role in commercial exports. In the first instance, however, the focus of concern will be on the distribution of grain contributed during relief efforts from surplus stocks of Western countries. ${ }^{230}$ The republics could also assist themselves in obtaining foreign grain even without a strong currency. For example, oil and other commodities produced in the republics could be traded until their currency is put on a stable footing. ${ }^{231}$ One publication has also suggested

227. For a description of those regulatory schemes, see Phillip Johnson \& Thomas Hazen, 1-3 Commodities Regulation (cited in note 217); Louis Loss \& Joel Seligman, 1 -7 Securities Regulation (Little, Brown, 3rd ed 1991).

228. Currently, there is no federal agency in the CIS with responsibility for regulating the commodity exchanges. Russia, however, has established a Russian Federation State Committee on Anti-Trust Policies and Support of New Economic Structures that is responsible for commodity exchange regulation in that most important state. It licenses the exchanges. Once licensed, the exchanges may trade goods produced in excess of state requirements. Such goods may be sold on the exchanges at market prices. Exchange transactions must be registered, but the exchanges set their own trading rules. Grigoryev, New Russian Exchange Regulations Set, Commersant 9 (April 1 , 1991). In August 1990, a Soviet study proposed a law to provide for the regulation of commodity exchanges by a state committee that would report to the Council of Ministers. Working Group Formed by M.S. Gorbachev and B. N. Yeltsin, Transition to the Market 168-71 Pt II (Aug 1990). Thereafter, the Soviet Economic Management Committee issued an edict prohibiting any overt or covert restrictions on the freedom to trade on the commodity exchanges. Yavlinsky Signs Package to Promote Private Enterprise, Commersant 6 (Nov 4, 1991).

229. Boris Yeltsin stated in a U.S. television interview that Russia will deal with the Chicago grain markets directly without working through the federal government. It is unclear what effect this will have on world markets or on overall grain purchasing policies by the CIS. Walter Goodman, $T V$ Critic's Notebook, Soviet Odd Couple Makes U.S. Debut, NY Times sec 1 p 7 col 1 (Sept 7, 1991).

230. Officials in the United States must not only worry about being on the losing end of a "Grand Bargain," they must also use due care to avoid inflationary price increases here as stocks are depleted. Scott Kilman, Soviet Crisis Adds Explosive Element to Slumping U.S. Agriculture Industry, Wall St J A3 col 2 (Sept 9, 1991); Scott Kilman, Soviet Pledge to Use 40\% of Food Aid Package for U.S. Wheat Sends Futures Prices Soaring, Wall St J C14 col 3 (Dec 4, 1991). Nevertheless, the United States is acting to finance large grain exports. Keith Bradsher, Banks in the United States Ply the Soviets With Loans for Grain Export, NY Times A6 col 1 (Sept 26, 1991).

231. Some such swaps are already occurring. William Dawkins, French Traders in $\$ 405 \mathrm{~m}$ Soviet Oil for Food Swap, Fin Times 29 col 7 (Nov 6, 1991); William Dawkins, French-Soviet Food-For-Oil Deal 'not in trouble, Fin Times $30 \mathrm{col} 1$ (Nov 20, 1991). See generally Cosgrove, Commodity Swaps Next Big 
that higher quality wheat produced in the CIS could be swapped for feed grain found in international markets. ${ }^{232}$ Of course, the republics should move to wean themselves from the need for importing feed grain by encouraging the production of fodder. ${ }^{233}$

\section{VIII \\ Conclusion}

"Ever since the collectivisation in the early 1930s, agriculture has been an outstanding weakness of the Soviet economy. No other branch appears so riddled with economic absurdities ...."234 Despite a record harvest in 1990, shortages developed and transportation bottlenecks caused grain to pile up on sidings throughout the former Soviet Union. Spoilage and waste then took a massive toll; farmers refused to sell to the state and crops were reduced because there was little incentive to plant or harvest a large crop. ${ }^{235}$ The collective farms clearly understand that selling grain to their government is not economically prudent; instead, they are using grain for animal feed and as additional payments to their workers, who use it in barter transactions.

The farms will not easily be enticed to part with their grain, and the shortage of middlemen and the lack of an efficient exchange distribution system pose formidable barriers to the implementation of a market economy. Incentives are needed to "jump start" the introduction of agricultural commodities into the economy of the republics and to stimulate the production of maximum amounts of grain or other agricultural products. These incentives would include land for grain exchanges as part of the privatization process. The existence of middlemen to bring the grain to market is also critical to the development of a market economy. These merchants also need incentives and assistance. Loans and grants to

Financial Investment?, J Comm 9A col 1 (special report) (June 25, 1990) (discussion of swap transactions); Henry T.C. Hu, Swaps, The Modern Process Of Financial Innovation And the Vulnerability of a Requlatory Paradigm, 138 U Pa L Rev 333 (1989) (same); Mark D. Young \& William L. Stein, Swap Transactions Under the Commodity Exchange Act: Is Congressional Action Needed?, 76 Georgetown L J 1917 (1988) (same); Note, Oil-Price Swaps: Should These Innovative Financial Instruments be Subject to Regulation by the Commodity Futures Trading Commission or the Securities and Exchange Commission?, 93 Dickinson L Rev 367 (1989) (authored by Laurenn S. Klett) (same).

232. Soviet Futures, The Economist 80 (May 11, 1991). See also Barry Newman, Locked Larders, Amid Soviet Disarray, Some Farmers Refuse to Ship Food to Cities, Wall St J Al col I (Nov 12, 1991) (Soviet Union does barter deal with Poland to reduce potato shortage).

233. Alexander Belozertsev, Grain Worth its Weight in Gold, Moscow News Wkly, No 49 (1988). See also Barry Newman, Locked Larders, Amid Soviet Dissaray, Some Farmers Refuse to Ship Food to Cities, Wall St $\mathrm{J} \mathrm{Al} \mathrm{col} 1$ (Nov 12, 1991) (Soviets "spent twice as much subsidizing meat in the 1980s as they did on health care").

The Ukraine is already asking the United States for assistance in new technology to increase grain production. Clifford Krauss, Ukrainian Leader and Bush Confer, NY Times A6 col 4 (Sept 26, 1991).

234. Anders Aslund, Gorbachev's Struggle for Economic Reform 96 (Cornell U Press, 1989).

235. Keith Bradsher, Gorbachev Asks A Huge Increase In Food Relief, NY Times Al col 5 (Sept 13, 1991); Craig R. Whitney, Aid at Any Price, NY Times A7 col 1 (Sept 12, 1991) ("With the winter fast approaching, and the harvest mostly still lying around in the fields waiting for the rains to rot it because the infrastructure of agricultural machinery and transport equipment has collapsed, the Soviets have already begun asking for help in feeding themselves."). 
middlemen for grain delivered to market would provide the incentives needed for distribution of grain to the market centers where it is needed.

Assistance will also be needed to foster exchanges in the republics. This will include communication facilities and technical assistance in establishing clearing mechanisms and dispute resolution procedures. By developing an exchange trading system, the republics can transport and process commodities in an orderly, rational and efficient manner. Funding for these incentives, communication facilities, and technical assistance would, in large measure, depend on grants from the West.

These proposals will be costly, but they will be more efficient than a relief effort that contains no stimulus for conversion to a market economy. The CIS is already asking for billions of dollars in aid to feed its population. ${ }^{236}$ Simply supplying grain for immediate consumption, however, will only prolong the misery of the conversion process. ${ }^{237}$ The program suggested above would provide incentives needed for the creation of a market economy that will hopefully eliminate the current shortages in the republics. These incentives would also increase the demand for a stable currency. When the recommended production incentives are exhausted, the existence of a hard currency could then serve its appropriate role as a medium of exchange and store of value that will assure maximum production, just as in any efficient market economy.

236. Soviet Union, Questioning the Begging, The Economist 54 (Sept 14, 1991); Francis X. Clines, Moscow Doubles Estimate of Need for Foreign Food, NY Times Al col 6 (Sept 20, 1991).

237. Of course, immediate relief should be given as an interim measure to avoid the effects of a famine. See Keith Bradsher, U.S. Has No Plan to Ask for Direct Aid for Soviets, NY Times A6 col 1 (Oct 3 , 1991) (U.S. official states that humanitarian aid will be available for the Soviets); The Perils of Togetherness, The Economist 15, 16 (Oct 12, 1991) (same); David Buchan, EC Pledges Soviet Aid, Fin Times 2 col 1 (Oct 8, 1991) (European community approves aid). See also, Goodwill is Enough, The Economist 101 (Dec 21, 1991-Jan 3, 1992) (discussion of international efforts needed to assist the Soviet republics). 
